University of Michigan Law School

University of Michigan Law School Scholarship Repository

1969

\title{
Mandatory Buy-Out Agreements for Stock of Closely Held Corporations
}

Douglas A. Kahn

University of Michigan Law School, dougkahn@umich.edu

Available at: https://repository.law.umich.edu/articles/546

Follow this and additional works at: https://repository.law.umich.edu/articles

Part of the Estates and Trusts Commons, Taxation-Federal Commons, Taxation-Federal Estate and

Gift Commons, and the Tax Law Commons

\section{Recommended Citation}

Kahn, Douglas A. "Mandatory Buy-Out Agreements for Stock of Closely Held Corporations." Mich. L. Rev. 68 (1969): 1-64.

This Article is brought to you for free and open access by the Faculty Scholarship at University of Michigan Law School Scholarship Repository. It has been accepted for inclusion in Articles by an authorized administrator of University of Michigan Law School Scholarship Repository. For more information, please contact mlaw.repository@umich.edu. 


\title{
MANDATORY BUY-OUT AGREEMENTS FOR STOCK OF CLOSELY HELD CORPORATIONS $\dagger$
}

\author{
Douglas A. Kahn*
}

TABLE of Contents

I. The Desirability of Buy-Out Agreements ........ 3

A. The Needs of the Decedent's Estate .......... 3

B. The Purposes of the Corporation ........... 8

II. Potentlal Purchasers $\ldots \ldots \ldots \ldots \ldots \ldots \ldots \ldots \ldots, 9$

III. Entity Purchase Plans $\ldots \ldots \ldots \ldots \ldots \ldots \ldots \ldots \ldots$. 11

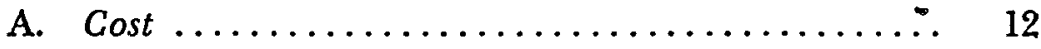

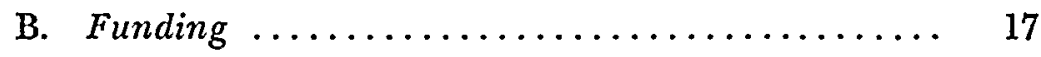

1. Reserve Funding .................. 17

2. Life Insurance Funding ............. 23

a. Tax Consequences ................ 24

b. Settlement Options ............... 33

c. Merits and Disadvantages of Insurance Funding ..................... 38

3. Payment with Promissory Notes ......... 43

C. Corporate Law Considerations ............ 46

IV. Cross-Purchase Plans $\ldots \ldots \ldots \ldots \ldots \ldots \ldots \ldots \ldots \ldots \ldots \ldots$

A. Advantages of the Cross-Purchase Plan ........ 52

B. Similarities to the Entity Purchase ......... 54

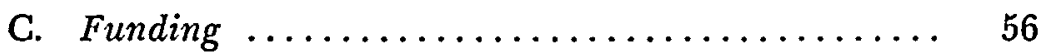

1. Life Insurance Funding $\ldots \ldots \ldots \ldots \ldots \ldots .56$

2. Other Means of Funding-Particular Difficulties with the Cross-Purchase .............. 62

V. Conclusion $\ldots \ldots \ldots \ldots \ldots \ldots \ldots \ldots \ldots \ldots \ldots \ldots \ldots \ldots$

$\dagger$ This article is drawn from Basic Corporate Taxation, a book previously written by the author and published in 1969 by the Institute of Continuing Legal Education, Ann Arbor, Michigan.

- Professor of Law, University of Michigan. B.A. 1955, University of North Carolina; J.D. 1958, George Washington University. 
buy-out of a shareholder's stock is a sale of his stock holdings In recent years such arrangements have, deservedly, become an increasingly popular planning device for shareholders in closely held corporations; they make it possible to limit the class of potential shareholders, provide liquidity for the estate of a deceased shareholder, and establish a value for stock which has no active market.

There are two popular categories of buy-out plans. If the prospective purchaser of a decedent's shares is the corporation that issued them, the plan is called an "entity purchase" plan, a "stock retirement" plan, or a "stock redemption" agreement. If the surviving shareholders are to purchase the decedent's stock, the plan is referred to as a "cross-purchase" agreement. A given plan may combine both types by providing that the corporation will redeem some of the shares and that the surviving shareholders will purchase the remainder.

Although it may be desirable in certain circumstances that a buy-out be optional on the part of either the purchaser or the seller, ${ }^{1}$ a mandatory agreement will usually be more appropriate. The focus of this Article is on mandatory agreements taking effect upon the death of a shareholder. ${ }^{2}$ Arrangements for a buy-out should, ideally, be prepared when a corporation is formed. In any event, an arrangement is likely to be fairer to all the parties when it is made before the death of a shareholder, since each shareholder is then uncertain as to whether he will be the survivor or the first to die. In the preparation of such an agreement, various tax and corporate law consequences must be anticipated, and other nontax considerations must be weighed. The purpose of this Article is to delineate some of the most important tax and corporate law considerations and to examine various methods of financing buy-outs. It will place par-

1. For example, when a corporation has made an election under subchapter $S$ (INr. REv. CODE of 1954, $\$ \$ 1371-78$ ), the corporation may wish to have the option to purchase the stock of a deceased shareholder so that it can protect its election, but it may not wish to be compelled to make the purchase. See D. KaHN, Basic Corporste TaxaTION 296-315.

2. Usually, it will also be desirable to impose restrictions on the inter vivos transfer of stock by a shareholder, since a buy-out which is mandatory at death will not in itself prevent a third party from purchasing the shareholder's stock before his death. In order to restrict such transfers effectively, certain procedures must be carefully observed. See notes 184-97 infra and accompanying text. Inter vivos restrictions may also be imposed by providing that the purchasers under the buy-out agreement have rights of first refusal during the shareholder's life.

Quite often a buy-out agreement will not be conditioned on death alone, but will also provide for the mandatory or optional purchase of a shareholder's stock during his life if he retires or becomes disabled. For an analysis of this type of arrangement, see Note, $A$ Closer Look at Disability "Buy-Outs" for the Close Corporation, 52 Mins. L. REv. 483 (1967). 
ticular emphasis on the merits and disadvantages of funding by means of life insurance.

\section{The Desirability of Buy-Out Agreements}

Buy-out agreements generally have two basic goals: the conversion of the decedent's interest in a closely held business into liquid assets and the prevention of the disposition of the decedent's stock to outside interests. The first of these serves the purposes of the deceased shareholder and his beneficiaries; the second primarily benefits the corporation and the continuing shareholders.

\section{A. The Needs of the Decedent's Estate}

When the amount of a decedent's gross estate ${ }^{3}$ is substantial, but a major part of his estate is represented by stock holdings in a closely held corporation, the executor often has difficulty obtaining sufficient liquid assets to satisfy the decedent's outstanding debts and to pay both the administrative expenses of the estate and the death taxes imposed by federal and state governments. A buy-out plan can ensure that the decedent's stock will be convertible into liquid assets when that is most necessary. That assurance of liquidity may be important to the shareholders in their personal estate planning. The following example may be useful:

I-A-1. $X$, a widower, and his brother, $Y$, each owns $50 \%$ of the stock of Widgets, Inc. $X$ dies leaving a taxable estate of $\$ 1,000,000 . X$ 's $50 \%$ interest in Widgets is valued at $\$ 910,000$; the proceeds of his life insurance are $\$ 120,000$; the aggregate value of his other stocks and securities and bank accounts is $\$ 30,000$. The remainder of his assets was used in satisfying his outstanding debts. The estate tax liability owing on $X$ 's death (ignoring state death taxes and funeral expenses) is $\$ 325,700$ and the liquid assets available total only $\$ 150,000$. The $\$ 175,500$ balance must be obtained from the Widget stock, but the executor is likely to have difficulty selling a minority interest in a closely held corporation. The executor might seek to have the corporation redeem part of $X$ 's stock, but if $Y$ refuses to cooperate with a redemption or if the parties cannot agree on the redemption price, the estate could be embarrassed.

Had $X$ and $Y$ anticipated this problem and executed a mandatory buy-out agreement prior to $X$ 's death, those difficulties would have been avoided. Two compatible co-investors, neither of whom knows which will survive, will probably reach an agreement on a

3. As used herein, the term "gross estate" refers to a decedent's gross estate for federal estate tax purposes. This encompasses far more than a decedent's probated estate. For example, insurance proceeds and jointly held property may be included in the decedent's gross estate even if they are excluded from his probated estate. See INT. REV. CODE of $1954, \$ \$ 2040,2042$. 
redemption plan and a valuation formula more readily than will a surviving shareholder and the executor of a decedent.

To guarantee liquidity for a shareholder's estate, the prospective purchaser must be obligated to purchase the decedent's stock, but the decedent's estate need not be required to sell. Liquidity is not always essential, since payment of federal estate taxes can sometimes be deferred. ${ }^{4}$ Nonetheless, it is wise to plan in such a manner as to ensure that there will be sufficient liquidity in case that should become necessary.

Furthermore, there are other sound reasons favoring a buy-out plan. A shareholder may prefer that the investment portfolio for his beneficiaries concentrate on security rather than on yield, and an investment in the corporation's business may not conform with that desire. For the same reason, the shareholder may wish to have his holdings diversified after his death, and that would require that his executor disengage his estate from the corporate business. The disadvantages of retaining a major portion of the decedent's estate in an investment in a closely held business are aggravated if the interest constitutes a minority share of the corporation, since there is a risk that the surviving shareholders will engage in oppressive tactics, such as increasing their salaries as corporate employees and reducing 'or eliminating dividends. Thus, the decedent's widow or surviving children may be "starved out" of the corporation and forced to sell at a sacrifice. ${ }^{5}$ The development of a deadlock betiveen the decedent's widow and the other shareholders may also prove unfortunate and should be avoided. ${ }^{6}$ By the use of a buy-out agreement, the disadvantages which often attend the bequest of shares in a closely held corporation may be minimized.

In some circumstances, however, a shareholder might desire that his interest in the closely held corporation be retained after his death. The earnings of the corporation may provide a substantially higher yield than the shareholder's widow would otherwise obtain, and the shareholder may have confidence in the stability of the business of the corporation. If the corporation is owned by one family, the shareholder may be confident that his widow will be

4. INT. REv. CoDE of $1954, \S 6166$. If the estate does not comply with the objective standards for deferral provided by $\S 6166$, it can still obtain a deferral under $\$ 6161$ (a)(2) as long as the executor can demonstrate that immediate payment would im. pose an undue hardship.

5. For a comprehensive treatment of the many techniques available to majority shareholders for squeezing out a minority shareholder, see F. O'NEAL \& J. DERWIN, EXpulsion OR Oppression of Business Associates: "SQUeEze-OUts" in SMall ENTERpRisfs (1961).

6. See 2 F. O’Neal, Glose Corporations \& 8.06 (1958). 
treated equitably by the other shareholders. Nevertheless, even close family members have been known to become enemies; and if a deceased shareholder's interest is not to be purchased, it will probably be desirable to provide at least for its conversion on death into an investment form that will maximize the widow's security, such as preferred stock or debentures which provide the holder with substantial or even exclusive voting rights in the event of a default in dividends or interest. ${ }^{7}$

A final advantage of a mandatory buy-out agreement is that the purchase price set in the agreement, whether it be a fixed dollar amount or one which is determined by means of a formula, may establish the value of the stock for estate tax purposes. ${ }^{8}$ For this result, the following conditions must be met: (1) the decedent's estate must be obligated to sell;9 (2) the agreement must prohibit the shareholder from disposing of the stock during his life without first offering it to the prospective purchaser or purchasers at the contract price; ${ }^{10}$ and (3) the purchase price must have been established through an arm's-length business bargain. ${ }^{11}$ In the case of family

7. Such an arrangement, however, may not be sufficient to prevent a squeeze-out. The majority shareholders might cause a merger or recapitalization of the corporation resulting in the elimination or dilution of the widow's protection. For a discussion of the means of protecting minority shareholders, see F. O'NEAL \& J. DERwiN, supra note 5; O'Neal, Arrangements IWhich Protect Minority Shareholders Against "SqueezeOuts," 45 MiNN. L. REv. 537 (1961).

8. See Helvering v. Salvage, 297 U.S. 106 (1936); Treas. Reg. § 20.2031-2(h) (1958); Rev. Rul. 59-60, \& 8, 1959-1 Cum. BuLL. 287, 243-44.

9. See United States v. Land, 303 F.2d 170 (5th Cir. 1962); Estate of Orville B. Littick, 31 T.C. 181 (1958), acq., 1959-2 CuM. BuLL. 5. When the decedent's executor is required to sell only upon the corporation's exercise of an option to buy, the purchase price established in the option agreement will control the estate tax valuation if the other tests are satisfied. Commissioner v. Bensel, 100 F.2d 639 (3d Cir. 1938); Wilson v. Bowers, 57 F.2d 682 (2d Cir. 1932). A mandatory buy-out, however, is a safer arrangement, particularly when the shareholders are members of the same family. If the decedent's estate has an option to sell, subject to the requirement that the executor first offer the stock to the corporation at a set price, the agreement does not impose sufficient restrictions on the sale of the stock to fix the valuation thereof since the executor need not sell at all. But the obligation to offer the stock to the corporation at a given price before making a sale may depress the market value of the stock. Worcester County Trust Co. v. Commissioner, 134 F.2d 578 (1st Cir. 1943). See C. Lowndes \& R. Kramer, Federal Estate ANd GifT TAXEs 484-91 (2d ed. 1962) for an excellent discussion of restrictive agreements.

10. Estate of Robert R. Gannon, 21 T.C. 1078, 1080 (1954) (holding that the value of a partnership interest was not determined by a purchase agreement which did not restrict sales during the partner's life); Treas. Reg. $\S 20.2031-2(\mathrm{~h})$ (1958); Rev. Rul. 5960 , \& 8, 1959-1 Cum. BuL. 237, 243-44. If the agreement provides the purchasers with first refusal rights at the contract price during the shareholder's life, that should be sufficient. Broderick v. Gore, 224 F.2d 892 (10th Cir. 1955); May v. McGowan, 194 F.2d 396 (2d Cir. 1952). An agreement which is binding only during the shareholder's life, however, does not fix the value of the stock. United States v. Land, 303 F.2d 107 (5th Cir. 1962); Mathews v. United States, 226 F. Supp. 1003 (E.D.N.Y. 1964).

11. See Treas. Reg. \& 20.2031-2(h) (1958); Rev. Rul. 59-60, \& 8, 1959-1 GuM. BuLL. 237, 243-44. 
corporations, the last condition may require that the purchase price be reasonable as determined in light of the potential growth of the business at the date the buy-out agreement is executed. ${ }^{12}$ Thus, a significant advantage of establishing the stock's estate tax valuation through a buy-out agreement is that it avoids the "horse-trading" negotiations which frequently attend a dispute with the Internal Revenue Service (Service) over the value of closely held stock.

It appears, then, that a buy-out agreement will usually be desirable for a deceased shareholder's estate. But such arrangements are not free from risks. One of the most troublesome is the possibility that a stock redemption will be deemed essentially equivalent to a dividend and taxed as such. ${ }^{13}$ Because of the attribution rules, ${ }^{14}$

12. The requirement of an arm's-length bargain creates uncertainties since that test is somewhat subjective; when the agreement is made among compatible family members, the best evidence usually available to demonstrate an arm's-length dealing is the reasonableness of the purchase price established in the agreement. See slocum v. United States, 256 F. Supp. 753 (S.D.N.Y. 1966), holding that when there was a business justification for an agreement at the date of execution, that agreement established the estate tax value of the shares, notwithstanding the parties' failure to amend the agreement to reflect a subsequent rise in value of the shares (from $\$ 100$ per share to more than $\$ 1,100$ per share) at least when the agreement was executed prior to the enactment of the estate tax. In Estate of Orville B. Littick, 31 T.C. 181 (1958), acq., 1959-2 GuM. BuLL. 5, the court sustained an agreement among shareholders who were members of the same family because there was a business purpose for the agreement, namely, to maintain the control of the present management. A surprising taxpayer success on this issue is May v. McGowan, 194 F.2d 396 (2d Cir. 1952), in which the court held that because the formula in the buy-out agreement resulted in a payment of zero for the decedent's stock, the estate tax value of the stock was also zero. In May, although the decedent was the father of the purchaser, the court found valid business considerations for the agreement in that the son had guaranteed repayment of a large debt of the decedent. While May is a significant case, it would still be prudent for planning purposes to establish a fair price for the stock that is subject to the purchase agreement. See Polasky, Planning for the Disposition of a Substantial Interest in a Closely Held Business (pt. III), 46 IowA L. REv. 516, 567-69, 572 (1961).

13. INT. REV. CODE of 1954, § 302(d). The net effect of a redemption of a shareholder's stock may bear greater resemblance to a dividend than to a purchase of the stock, and, if so, it is treated accordingly. For example, assume that $A$ owns sixty of the one hundred outstanding shares of stock of the $X$ corporation and $B$ owns the other forty shares. $X$ has sizeable earnings and profits. $X$ redeems thirty shares of $A$ 's stock for $\$ 30,000$ and twenty shares of $B$ 's stock for $\$ 15,000$. Since, both before and after the redemption, $A$ and $B$ owned respectively $60 \%$ and $40 \%$ of $X$, the only significant alteration made by the "redemption" was that $\$ 45,000$ cash was withdrawn from the corporation. Thus, it is likely that the putative "redemption" will be treated as the distribution of a dividend. The criteria for determining whether or not a stock redemption constitutes a dividend are intricate and should be studied carefully. For an analysis of this question, see B. Birtker \& J. Eustice, Federdil InConie TAxation of Corporition AND Shareholders ch. 7 (2d ed. 1966); D. KahN, supra note 1, ch. I. In addition, it the surviving shareholders are obligated to purchase the decedent's shares, and if the corporation redeems those shares in their stead, thereby discharging the obligation, the redemption will constitute a dividend to the surviving shareholders. C. Lowndes \& $R$. KRAMER, supra note 9, at 875 .

14. The attribution rules provide that when stock is nominally owned by or for one individual or entity, it will be considered as owned by certain other closely related individuals or entities as well. INT. REv. CODE of $1954, \S 318$. It would be unrealistic to 
this possibility exists even if all of a decedent's stock is redeemed. However, to the extent that a redemption qualifies under section 303 of the Internal Revenue Code (Code), the distributions to the shareholders do not constitute dividends, and when the benefits of that provision are available, they often prove too valuable to forgo. ${ }^{15}$ While a cross-purchase plan is not subject to this difficulty, it creates other problems which are discussed later.

There is a further danger if the purchase price fixed in the buyout agreement is not treated as determinative of the value of the stock. ${ }^{16}$ If the amount distributed by the corporation in payment for the stock is deemed greater than the stock's value, the excess will not constitute a distribution in redemption of the stock, and consequently will not be protected by section 303 or $302(a)^{17}$ of the Code.

examine the net effect of a stock redemption solely from the viewpoint of the shareholders whose stocks were redeemed, without accounting for the stockholdings of closely related persons. Accordingly, in determining whether a stock redemption constitutes a dividend, the rules of attribution embodied in $\S 318$ of the Internal Revenue Code (Code) are usually applied. INT. REv. CoDE of 1954, §302(c). For example, if $C$ and $D$ each owns $50 \%$ of the outstanding stock of the $Y$ Corporation, and if the $Y$ Corporation redeems all of $C$ 's stock, the redemption is completely disproportionate as between the two shareholders and, therefore, will usually be treated as a purchase of $C$ 's stock rather than as a dividend distribution. If $C$ and $D$ are husband and wife, however, it might be more accurate to view their stockholdings as combined in a single family unit; in that event, the redemption would not be disproportionate to any extent. Under \$ 318(a)(1) of the Code, a shareholder's stock will be attributed to his or her spouse and treated as if the latter also owned it. Consequently, if C's wife owns all the remaining shares, the redemption of $C$ 's stock will usually constitute a dividend. Nevertheless, in certain circumstances, defined in $\S 302$ (c)(2) of the Code, the attribution rules are disregarded. For a discussion of the attribution rules established by $\S 318$, see B. BrrTrker \& J. EusticE, supra note 13, at 280-84; D. KAHN, supra note 1, ch. I.

15. Section 303 of the Code provides that if certain conditions are satisfied, the redemption of stock which was included in the gross estate of a decedent will be treated as a purchase rather than as a dividend. The benefits of $\S 303$ can be claimed for only that amount of stock which is equal to the sum of the decedent's federal and local death taxes and the administrative and funeral expenses that were allowable as federal estate tax deductions for the decedent's estate. The administrative and funeral expenses need only be allowable deductions; it is not required that they actually be deducted. To qualify, the estate tax valuation of the redeeming corporation's stock that is included in the decedent's gross estate must exceed either $35 \%$ of the value of the decedent's entire gross estate or 50\% of his taxable estate. If stocks of each of two or more corporations are included in the decedent's gross estate, and if they exceed $75 \%$ of the value of the outstanding stocks of such corporations, then the value of such included stocks may be totalled for purposes of determining whether or not the $35 \%$ $50 \%$ test has been satisfied. Only stock redeemed within a prescribed time period (usually about $41 / 2$ years) following the decedent's death will qualify. For a further discussion, see notes 171-73 infra and accompanying text. For a discussion of the requisites of $\S 303$ and planning techniques for using it, see Barrett, How To Handle Distributions in Redemption of Stock To Pay Death Taxes-\$303, 2 P-H TAx IDEAS I $26,004.1$ (1965).

16. See text accompanying notes 8-12 supra.

17. INT. REV. CODE of 1954, § 302(a) provides that if certain conditions are met, a redemption will be "treated as a distribution in part or full payment in exchange for the stock." This section will apply if any one of the following four conditions is 
Thus, the amount of the difference might be characterized either as a dividend distribution or as a gift from the surviving shareholders, giving rise to gift tax consequences. If the amount distributed by the corporation in payment of the stock is deemed less than the stock's value, the shareholder will be required to pay estate taxes based on a value in excess of that which he realized-a result that could cause considerable hardship. Indeed, if the payment in redemption is substantially less than the stock's value, the estate tax liability incurred on account of the stock may actually exceed the amount realized on its redemption. Thus, care should be taken that the agreement fix the estate tax value of the stock, and that, in any event, the established price be reasonable so that a failure to comply with the above-mentioned requisites will not have disastrous consequences.

\section{B. The Purposes of the Corporation}

Besides its advantages for the estate of the deceased shareholder, a buy-out arrangement may also be desirable for the corporation and the surviving shareholders. The buy-out can prevent a deadlock or harassment by those who inherit stock from the decedent. Moreover, a decedent's widow and the surviving shareholders will often have conflicting goals for the corporation, and that conflict may complicate the management of the company. The question whether corporate earnings should be distributed as dividends or reinvested in the business, and the question of the amount of risk that the business should undertake in entering new ventures are examples of potential areas of conflict which could be eliminated through a buy-out agreement.

Additional considerations arise if the corporation has made an election under subchapter S. ${ }^{18}$ In that case, it is important that a

met: (l) the redemption is not essentially equivalent to the dividend [\$ 302(b)(1)]; (2) the distribution is substantially disproportionate [as defined in $\& 302(\mathrm{~b})(2)(\mathrm{C})$ ] with respect to the shareholder and, immediately after the redemption, the shareholder owns less than $50 \%$ of the total voting power of all classes of stock entitled to vote [s 302(b)(2)]; (3) the redemption is of all the stock of the corporation owned by the shareholder [\$ $302(\mathrm{~b})(3)]$; or (4) the redemption is of stock issued by a railroad pursuant to a reorganization plan under $\$ 77$ of the Bankruptcy Act, 11 U.S.C. $\$ 205$ (1964) [§ 302(b)(4)]. For a discussion of these provisions, see B. BIrTKER \& J. EusTICE, stupra note 13 , at $279-94$.

18. Subchapter S (INT. REv. CoDE of 1954, $\$ \$ 1371-78$ ) permits a corporation complying with certain requisites to elect that its earnings be included in the income of its shareholders. If such an election is made, the corporation pays no income tax other than a capital gains tax imposed in certain circumstances (\$1378). See D. KaHN, supra note 1 , ch. V. Buy-out arrangements for the redemption or purchase of the stock of a subchapter $\mathbf{S}$ corporation raise peculiar problems and considerations which are not dealt 
shareholder be prevented from bequeathing his stock to a party who would refuse to consent to the election ${ }^{19}$ or to a trust, ${ }^{20}$ since either of those contingencies would terminate the benefits of subchapter S. A buy-out can protect the election by eliminating the possibility of such a bequest.

Most of the purposes of the deceased shareholder's estate can be satisfied by requiring the prospective purchaser to purchase the stock if the estate elects to sell. But for the purposes of the continuing shareholders and the corporation, and for the purpose of fixing estate tax values, the decedent's estate must be obligated to sell if the prospective purchaser elects to buy. Consequently, in most circumstances, a mandatory buy-out will be the most desirable arrangement since it will satisfy the needs of both parties.

\section{Potential Purchasers}

Once it has been determined that a buy-out plan is desirable, the potential purchaser of a shareholder's interest must be selected. As indicated above, the purchaser is usually either the corporation (an entity purchase) or the surviving shareholders (a cross-purchase), although a combination of the two will sometimes be employed. But there are other possibilities as well. The most significant of these is a provision that part of the deceased shareholder's stock will be purchased by a trust held under a qualified deferred compensation plan established by the corporation for its employees. ${ }^{21}$ The Service prohibits a qualified trust fund from acquiring the employer's stock unless it is purchased for the "exclusive benefit of the employees or their beneficiaries" and unless local law permits such investments. ${ }^{22}$ Four conditions must be fulfilled to satisfy the exclusive-benefit requirement: (1) the stock must be purchased at no more than its fair market value; (2) the stock must provide a fair return commensurate with the prevailing rate; (3) sufficient liquidity must be maintained in the trust fund to permit distributions according to the

with in this Article. For an analysis of those problems, see Crumbley, Buy and Sell Agreements for Subchapter S Corporations, 108 TRUSTS \& ESTATES 17 (1969).

19. INT. REv. CODE of 1954, § 1372(e)(1).

20. INT. REv. CoDE of 1954, $\S \S 1371(a)(2), 1372(e)(3)$. The same result will follow upon a bequest to a nonresident alien. INT. REv. CoDE of 1954, §§ 1371(a)(3), 1372(e)(3).

21. There are many advantages to using the trust funds for that purpose. It provides the employees of the corporation with an equity interest in the business and serves as a convenient source of liquid assets. Moreover, in some circumstances, there are tax advantages to the employees who receive distributions of such stock on retirement. INT. REv. CODE of 1954, § 402(a)(1); Treas. Reg. § 1.402(a)-1(b) (1956).

22. Rev. Rul. 65-178, 1965-2 Cum. BuLl. 94, 104. 
terms of the plan; and (4) the safeguards and diversity that a prudent investor would adopt must be present. ${ }^{23}$ The common stock of most closely held corporations will not satisfy the exclusive-benefit test both because such stock usually has no available market and because frequently few or no dividends will ever have been paid on the stock, so that there will not be a fair return. Nevertheless, the Service has held in a Technical Advice Memorandum that a trust which maintains separate accounts for each employee satisfies the exclusive-benefit test so long as the plan permits each employee at his option to direct that part of his trust account be invested in his employer's stock, and so long as the trustees are required to abide by the decision of an employee as to how much of his account shall be so invested. ${ }^{24}$ This Memorandum is buttressed by a subsequent published ruling concerning profit-sharing trusts. ${ }^{25}$ The requirement of individual employee accounts makes it unlikely that such an arrangement will be feasible for most pension plans ${ }^{26}$ although it may be useful for profit-sharing plans. When funds of a qualified trust are invested in the stock or securities of the employer, the trustee is required to give notice to the Service of such investment and to disclose the reasons for the investment and the circumstances under which it was made. ${ }^{27}$

In some situations it may be feasible to recapitalize the corporation so that the deceased shareholder's estate receives preferred stock in exchange for common. The preferred shares may then be sold to the trust as long as they comply with the exclusive-benefit test. ${ }^{28}$ However, if the recapitalization is effected after the shareholder's death, the planner must give due regard to section 306 of the Code. ${ }^{29}$

23. Rev. Rul. 65-178, 1965-2 Cum. Burl. 94, 104.

24. The memorandum was from the National Office to the District Director, San Francisco, dated Nov, 27, 1961. P-H Pension \& Profit Sharing SERv. \$ 11,983. For a discussion of this issue, see D. Rothman, Establisfing \& AdMinistering Pension \& Profit Sharing Plans \& Trust Funds 160-63 (1967).

25. Rev. Rul. 65-178, pt. 5(r), 1965-2 GuM. Bull. 94, 125.

26. "Money purchase" pension plans might adopt separate investment accounts for each employee's share, but most pension trusts could not readily adopt separate accounts.

27. Treas. Reg. § 1.401-1(b)(5)(ii) (1956).

28. See text accompanying note 23 supra.

29. In general, if "section 306" stock is sold, the entire proceeds of the sale may constitute ordinary income to the recipient; if the stock is redeemed, the proceeds constitute a corporate distribution subject to $\S 301$ and thus will frequently be treated as ordinary income to the shareholder. INT. REv. CoDE of 1954, $\$ 306(a)$. See B. Birtker \& J. Eustice, supra note 13, ch. 8, for a thorough discussion. "Section 306" stock is defined in INT. REv. CODE of 1954, $\$ 306(\mathrm{c})$ :

(1) In general. ...

(A) ... Stock (other than common stock issued with respect to common 
The use of trust funds for stock purchase purposes can be a highly valuable device, but the path to this modern-day Valhalla is no less perilous than the journey to the original, and the planner should proceed with both caution and private rulings.

\section{Entity Purchase Plans}

The entity purchase plan is the most popular form of buy-out arrangement. Indeed, if a buy-out is to be arranged, there are a number of good reasons for providing that the corporation will be the purchaser of a decedent's shares. However, there are many considerations relevant to the preparation of such an arrangement, and all must be carefully appraised. The applicable state laws must be examined in order to determine what measures have to be taken to comply with those laws. A similar examination of the means by which the corporation will obtain the funds needed for the buy-out is required. A funded reserve may be established, life insurance may be purchased, the corporation's notes may be used, or combinations of these methods may be employed; each of those means will have certain advantages and disadvantages. Since the principal competition to the entity purchase is the cross-purchase agreement, ${ }^{30}$ the following discussion will occasionally contrast the two.

stock) which was distributed to the shareholder selling or otherwise disposing of such stock if, by reason of section 305 (a), any part of such distribution was not includible in the gross income of the shareholder.

(B) ... Stock which is not common stock and-

(i) which was received, by the shareholder selling or otherwise disposing of such stock, in pursuance of a plan of reorganization (within the meaning of section $368(\mathrm{a})$ ), or in a distribution or exchange to which section 355 (or so much of section 356 as relates to section 355 ) applied, and

(ii) with respect to the receipt of which gain or loss to the shareholder was to any extent not recognized by reason of part III, but only to the extent that either the effect of the transaction was substantially the same as the receipt of a stock dividend, or the stock was received in exchange for section 306 stock.

For purposes of this section, a receipt of stock to which the foregoing provisions of this subparagraph apply shall be treated as a distribution of stock.

(C) ... Except as otherwise provided in subparagraph (B), stock the basis of which (in the hands of the shareholder selling or otherwise disposing of such stock) is determined by reference to the basis (in the hands of such shareholder or any other person) of section 306 stock.

(2) Exception where no earnings and profits.-For purposes of this section, the term "section 306 stock" does not include any stock no part of the distribution of which would have been a dividend at the time of the distribution if money had been distributed in lieu of the stock.

Stock sold to the trust will not qualify under $\$ 303$ of the Code since it is not redeemed by the corporation. Consequently, the priority of $\$ 303$ over $\S 306$ [see Treas. Reg. $\$ 1.305-2$ (d) (1955)] is of no assistance. Preferred stock issued after the decedent's death will probably be tainted by $\$ 306$ of the Code. Therefore, all or part of the amount received as consideration for the sale of such stock may be characterized as ordinary income, irrespective of the vendor's basis in the stock. \$ 306(a)(1). See D. KAHN, supra note 1 , ch. I. 


\section{A. Cost}

There are a variety of means available to fix the redemption price of stock under a buy-sell agreement. ${ }^{31} \mathrm{~A}$ common method is the selection by the parties of a specific dollar figure. If this is done, however, the agreement should include a provision requiring periodic review of that figure every one or two years, ${ }^{32}$ and a further provision that if a new figure is not set within one or two years prior to a shareholder's death, the amount set in the agreement is to be disregarded ${ }^{33}$ and an alternative method of pricing is to apply. There are many other means of valuation that might be employed, such as a capitalization-of-earnings formula, ${ }^{34}$ a determination of book value, an appraisal of the corporation's tangible assets by a selected appraiser or by members of a selected group of appraisers, ${ }^{35}$ an arbitration provision, or a weighted combination of any of these methods. ${ }^{30}$

If the shareholders are members of the same family unit, they should resist the temptation to establish a low value for a deceased shareholder's stock. A realistic valuation is important not only for establishing the estate tax value of the stock, ${ }^{37}$ but also because a low valuation may deprive the shareholder's estate of the use of section 303 of the Code if the established value of the decedent's stock is less than both thirty-five per cent of the decedent's gross estate and fifty per cent of his taxable estate. ${ }^{38}$

Once the price is established, the means by which it will be paid

31. Corneel, Valuation Techniques in Buly-Sell Agreements: Effect on Gift and Estate Taxes, N.Y.U. 24TH INST. ON FED. TAX. 631 (1966).

32. The stock redemption agreement should include a page for inserting (1) the established figure, (2) the signatures of the parties, and (3) the date of execution of that page.

33. The agreement should state that the figure is effective only if established within a given period prior to the shareholder's death.

34. The capitalization rate should be agreed upon by the parties and stated in the agreement. That rate may be determined by considering the price-earnings ratio of comparable companies whose stock is sold on the open market and therefore easily valued. The annual earnings to be capitalized may be determined under a specific formula when the use of such a procedure is desirable. For example, if the corporation's earnings are erratic, the parties may wish to average the last five years' earnings and capitalize that amount; or in some circumstances, they may wish to average the three years of the last five that had the highest (or the lowest) earnings.

35. An appraisal of assets may be especially appropriate if the corporation is a real estate holding company.

36. There is considerable literature on the subject of valuation, and the reader may locate writings discussing the appropriate methods of valuing the very kind of business in which his corporation is engaged.

37. See text accompany notes 8-12 supra.

38. See note 15 supra. 
becomes an important consideration. One of the attractive features of the entity purchase is that the use of corporate funds to redeem a deceased shareholder's stock usually imposes a smaller net cost on the corporation and the surviving shareholders than does a crosspurchase agreement.

Since the amount paid to redeem a shareholder's stock is not deductible,$^{30}$ an accurate determination of the actual cost of purchasing the decedent's stock should reflect the amount that the corporation must earn before taxes in order to make the payment. If, for example, the $X$ Corporation is in a forty-eight per cent income tax bracket, and it agrees to redeem a shareholder's stock for 52,000 dollars, $X$ must earn 100,000 dollars to have sufficient funds available after taxes for the redemption. Of course, it might not be necessary for the corporation to draw on its earnings in order to redeem a shareholder's stock; instead it might be able to contract its capital investment and distribute previously contributed capital. But in the usual buy-out arrangement, a contraction of the corporation's business investment will not be desirable and may not even be feasible. Moreover, the shareholder's stock will often be valued at an amount much greater than his capital contributions, and the earnings of the corporation would probably be the best available source for the funds needed to acquire the stock.

In a cross-purchase plan, the surviving shareholders will usually obtain from the corporation the funds needed to purchase the decedent's stock. ${ }^{40}$ If the funds must be withdrawn as dividends, the additional cost to the corporation and the shareholders can be severe. A comparison between the above example of the cost of an entity purchase and the following illustration of a cross-purchase arrangement reveals the disparity.

III-A-I. The $X$ Corporation is in a $48 \%$ tax bracket and has three equal shareholders, $A, B$, and $C$. These three have agreed that the $\mathrm{X}$ stock of the first to die will be purchased by the two survivors for $\$ 52,000 . A, B$, and $C$ are each in the $60 \%$ tax bracket. ${ }^{41}$ When $A$ dies,

39. Distributions in redemption are not business expenses under $\S 162$ of the Code, and will likely constitute a capital expenditure, which is nondeductible under $\S 263$ of the Code.

40. If the cross-purchase agreement is funded by life insurance, the premiums for that insurance will usually be paid from funds withdrawn from the corporation, so the comparison of relative costs of a direct purchase of the stock will be equally applicable to the payment of insurance premiums. In some circumstances, the net cost of purchasing life insurance for shareholders who are also employees of the corporation may be reduced by utilizing a split-dollar insurance plan. Such a plan, however, should probably not be used to fund a buy-out agreement. See notes 238-45 infra and accompanying text. See also Note, Estate Planning for the Disposition of Control of a Family Corparation, 52 MrNs. L. REv. 1019, 1030 n.46 (1968).

41. The withdrawal from the corporation of a large sum which will be included in 
$B$ and $G$ wish to withdraw sufficient funds from $X$ to pay $\$ 52,000$ to $A$ 's estate. Since $B$ and $C$ will retain only $40 \%$ of dividends paid to them after taxes, they must withdraw $\$ 130,000$ to obtain the $\$ 52,000$ needed. The corporation will have to earn $\$ 250,000$ in order to have $\$ 130,000$ available after taxes to distribute to $B$ and $C$. Thus, under a cross-purchase plan, the net cost of obtaining $\$ 52,000$ from the corporation is $\$ 250,000$ as compared with $\$ 100,000$ under the entity purchase plan.

When the amounts distributed to the surviving shareholders can be made in a deductible form ${ }^{42}$ - such as salary, interest, or rent-the difference in net cost is less dramatic, but the entity purchase is still the cheaper method, unless the shareholders are in an income tax bracket lower than that of the corporation..$^{43}$

III-A-2. Assume the same facts as in example III-A-I except that $B$ and $C$ are able to withdraw funds from $X$ as deductible expenses, such as salary. In order to obtain the needed $\$ 52,000$ after taxes, $B$ and $C$ must withdraw $\$ 130,000$ from $X$; but since the amounts paid to $B$ and $C$ are deductible, $X$ need earn only $\$ 130,000$ to provide $B$ and $G$ with after-tax dollars of that amount. Thus, even though the payments to the shareholders are deductible, the net cost of the crosspurchase plan $(\$ 130,000)$ will be $\$ 30,000$ greater than the cost of the entity plan.

It should not be assumed, however, that the entity purchase will be superior to a cross-purchase plan in every case. Both plans have their distinctive merits and disadvantages, and both should be considered carefully in the context of the specific circumstances and goals that exist in each individual situation.

One disadvantage of the entity purchase is that the corporation derives no tax benefit from the acquisition of the decedent's stack regardless of whether it cancels the redeemed shares or carries them as treasury stock. The corporation cannot recognize a gain or loss on the sale of its own stock, including treasury stock, ${ }^{44}$ and consequently its basis in the redeemed shares is meaningless. In contrast, when a surviving shareholder acquires stock under a cross-purchase

the shareholder's gross income would probably be taxed in a higher bracket than $60 \%$; but for convenience, the effective tax rate on amounts withdrawn is here treated as remaining stable at $60 \%$. If the higher tax rates were used in making the computations, the expense of withdrawing funds from the corporation would be increased, and therefore the comparison of the costs of the two buy-out methods would be even more dramatic.

42. This is sometimes possible when the corporate funds are withdrawn annually for the purpose of paying life insurance premiums, if the annual distribution does not exceed a reasonable salary, and if the funds are paid as such.

43. If the shareholders are in a lower tax bracket than the corporation and funds can be withdrawn from the corporation in a deductible form, the cross-purchase plan will be a less expensive arrangement. That situation, however, is atypical.

44. INT. REV. CODE of 1954, § 1032. 
agreement, his basis in the acquired stock is meaningful if he disposes of the stock prior to his death.

One risk that attends an entity purchase is the possibility that the corporation's purchase of one shareholder's stock may be treated as a constructive dividend to the other shareholders, whose percentage of equity in the corporation is increased by virtue of the redemption. Fortunately, there are buoys in these troubled waters, ${ }^{45}$ and if the planner navigates carefully, he can steer a safe course which avoids adverse tax consequences to the surviving shareholders. In general, the primary obligation to purchase the decedent's stock must rest exclusively on the corporation; the other shareholders must have no obligation to purchase anything, but they may accept a secondary liability arising if the corporation defaults. ${ }^{40}$

A more important danger of the entity purchase is the possibility that the redemption of stock will be deemed essentially equivalent to a dividend and taxed accordingly. The applicable principles in this area are highly technical and require great caution, but dividend treatment can be avoided. ${ }^{47}$ The difficulty may be seen best by an example:

III-A-3. $A$ owns fifty shares of the outstanding stock of the $X$ Corporation, and $A$ 's brother, $B$, owns the remaining fifty shares. $A$ wishes to make a testamentary bequest to $B$, and to leave his residuary estate to his wife, $W$. If, upon $A$ 's death, the $X$ Corporation redeems $A$ 's fifty shares of stock from his estate, the redemption will not be deemed substantially disproportionate or a termination of interest, because $A$ 's estate will have attributed to it the fifty shares of stock owned by $B$ who is a beneficiary of the estate. ${ }^{48}$

Proper tax planning prior to $A$ 's death could prevent the difficulties on redemption. One possible plan is to eliminate mention of $B$ 920.

45. Rev. Rul. 59-286, 1959-2 Cum. BuLl. 103; Rev. Rul. 58-614, 1958-2 CuM. BuLl.

46. See note 179 infra and accompanying text.

47. See notes 13-15 supra and accompanying text.

48. INT. REv. CoDE of 1954, $\$ 318(a)(3)$ (A). It is theoretically possible to avoid attribution in this example by first distributing $B$ 's bequest to him and then effecting the redemption of the stock, since, in that event, $B$ will not be a beneficiary of the estate at the time of redemption as long as certain conditions are satisfied. Treas. Reg. $\$ 1.318$ 3(a) (1955). One of the conditions is that there must be no more than a remote possibility that the estate will seek contribution from the beneficiary for payment of claims against it or for expenses of administration. Since this is a dangerous planning device, it is not recommended. See, e.g., Estate of Webber v. United States, 263 F. Supp. 703 (E.D. Ky. 1967), affd., 404 F.2d 411 (6th Cir. 1968), for an indication of the seriousness of that danger. In $W$ Webber, the beneficiary of several specific bequests had received distribution of all of his bequests prior to a stock redemption but was nevertheless deemed a beneficiary of the estate at the date of redemption because there was a possibility that he would have to contribute to the estate or to other beneficiaries a pro rata portion of the estate's tax liabilities. It must be remembered, too, that a residuary legatee of an estate does not cease to be a beneficiary until the estate is closed. Rev. Rul. 60-18, 1960-I CuM. BurL. 145. 
from $A$ 's will, and to utilize an inter vivos revocable trust as a vehicle for transferring $B$ 's interest. Another is to place $A$ 's stock in $X$ in a revocable trust ${ }^{49}$ which is insulated from attribution of $B$ 's stock as long as neither $B$ nor any person who has constructive ownership of $B$ 's stock is a beneficiary of the trust. ${ }^{50}$

If the stock is included in the deceased shareholder's gross estate, the dividend question can be avoided to the extent that it is covered by section 303,51 or by section $302(\mathrm{~b}),{ }^{52}$ or even by sections 331 (a)(2) and $346 . .^{53}$ Section 303, for example, applies even when the decedent's stock is held in a revocable trust at the time of his death, so long as the stock is included in the decedent's gross estate. ${ }^{54}$ When the dividend problem is solved, there will usually be no tax consequences on the redemption of stock included in the decedent's estate. Under section 1014 of the Code, the basis of such stock is equal to its fair market value at decedent's death, ${ }^{55}$ so there is likely to be little or no gain realized on the redemption of the stock. If the stock included in the decedent's estate is section 306 stock, $^{56}$ it loses that taint on the decedent's death. ${ }^{57}$ Thus, section 306 should not pose difficulties unless there is a corporate reorganization or stock dividend paid after the decedent's death and before the redemption, and unless the newly issued stock constitutes section 306 stock. Even then, a redemption of the newly issued section 306 stock will not have adverse tax consequences if the redemption qualifies under section 303.58

49. This second method should not be employed if the $X$ corporation has made an election under subchapter $S$ since the transfer to the revocable trust may terminate the election. Treas. Reg. $\S \S 1.1371-1(\mathrm{~d})(\mathrm{l}),-1(\mathrm{e})(1959), 1.1372-4$ (b)(3) (1959).

50. See INT. REv. CODE of 1954, § 318(a)(3)(B); note 14 supra.

51. See note 15 supra and accompanying text.

52. See note 17 supra.

53. INT. REv. CoDE of 1954, \& 381(a)(2) provides that amounts received in partial liquidation of a corporation, as defined in $\S 346$ of the Code, shall be treated as payments in exchange for stock.

54. Property held in a revocable trust will be included in the donor's gross estate. INT. REV. CODE of 1954, § 2038.

55. This is true unless the estate elects the alternate valuation date (INr. REv. CoDE of 1954, \& 2032), in which case the date on which the stock is valued for estate tax purposes controls. INT. REV CODE of 1954, § 1014(a). As used in § 1014, the phrase "fair market value" refers to the value determined under the estate tax laws [Treas. Reg. \& 1.1014-1(a) (1957)]; in most cases, the estate tax value will equal the purchase price of the stock.

56. See note 29 supra. "Section 306" stock is discussed in B. BITTRER \& J. EusTice, supra note 13, ch. 8.

57. INT. Rev. Code of 1954, \& 306(c).

58. Treas. Reg. $\S 1.303-2(d)$ (1955) provides that $\S 303$ takes precedence over $\$ 306$. 


\section{B. Funding}

Upon the death of a shareholder who is a party to an entity purchase agreement, the corporation must have sufficient assets to redeem the shareholder's stock. There are several ways for the corporation to raise the necessary funds. ${ }^{59}$

\section{Reserve Funding}

The corporation may seek to raise the necessary funds by investing a portion of each year's corporate earnings in liquid assets that will constitute a funded reserve. One difficulty with a self-funding plan is that a shareholder might die soon after the plan is executed, before the corporation has had time to accumulate a sufficient surplus in its reserve fund to redeem his stock.

But even if the shareholders obligingly live long after the plan is established, the accumulation of a sizeable surplus may have adverse tax consequences, for the corporation may be subjected to the imposition of an accumulated earnings tax..$^{60}$ That tax, which is imposed in addition to the normal corporate tax and surtax, ${ }^{61}$ applies to corporations "formed or availed of for the purpose of avoiding the income tax with respect to its shareholders or the shareholders of any other corporation, by permitting earnings and profits to accumulate instead of being divided or distributed." 62 If the earnings and profits of the corporation are accumulated beyond the reasonable needs of the business, ${ }^{63}$ the corporation is presumed to be availed of for the proscribed purpose unless it proves the contrary. ${ }^{64}$ In determining the amount of the accumulated earnings tax, the

59. For example, a third party may be used as an interim financing intermediary for the corporation in an arrangement similar to the "ABC" transactions employed in the oil and gas field. See Sexton, Providing Security for the Outgoing Stockholder and Avoiding Tax Disadvantages to Selling and Remaining Stockholders, N.Y.U. 24TH INST. ON FED. TAX. 555, 584-85 (1966). In some circumstances, the corporation may be able to borrow the needed funds directly from a third party and to repay the loan from subsequent earnings. Cf. Murphy Logging Co. v. United States, 387 F.2d 222 (9th Cir. 1967).

60. INT. REv. CODE of 1954, $\$ \$ 531-37$. The accumulated earnings tax is a tax of $271 / 2 \%$ or $381 / 2 \%$ which is imposed on accumulated taxable income. "Accumulated taxable income" refers to the corporation's taxable income modified in accordance with $\$ 535$ of the Code. One important modification is a deduction for dividends paid, although many other adjustments are also applicable. In addition, the temporary surtax imposed by $\$ 102$ of Public Law 90-364 (june 28, 1968) (INT. REv. CoDE of 1954, 851) scrves to increase the amount of the accumulated earnings surtax.

61. These taxes are imposed under INT. REv. CoDE of 1954, $\$ 11$.

62. INT. REv. CODE of 1954, § 532(a).

63. The phrase "reasonable needs of the business" includes the reasonably anticipated needs of the business. INT. REv. CODE of 1954, $\$ 537$.

64. INT. REv. CODE of 1954, § 533 . 
accumulated taxable income ${ }^{65}$ of a corporation is reduced by the sum of dividends paid plus an accumulated earnings credit. ${ }^{66} \mathrm{Gen}$ erally, the accumulated earnings credit is equal to that part of the earnings and profits for the taxable year that are retained for the reasonable needs of the business. ${ }^{67}$ In no event will the accumulated earnings credit be less than the amount by which 100,000 dollars exceeds the corporation's accumulated earnings and profits determined as of the end of the preceding taxable year. ${ }^{68}$

In the great majority of cases litigated under the accumulated earnings tax provisions, the parties have treated the question whether the corporation accumulated earnings and profits beyond the reasonable needs of the business as dispositive. ${ }^{69}$ That question, however, should be only evidentiary of the crucial issue-whether the corporation's accumulation was for the purpose of avoiding a shareholder's income tax.

Recently, in United States v. Donruss, ${ }^{70}$ the Supreme Court settled the question whether the accumulated earnings tax may be applied whenever the proscribed purpose is present or only when that purpose is the dominant motive for the accumulation. The Court held that if any purpose of the corporation for accumulating its earnings was the proscribed one, the tax is applicable even though the proscribed purpose was not dominant. There will probably be few instances when a taxpayer can successfully negate the inference that tax avoidance was at least one of the purposes for the accumulation of earnings by a closely held corporation. Thus, the principal

65. See note 60 supra.

66. INT. REv. CODE of 1954, § 535(a).

67. INT. REv. CODE of 1954, §535(c). The credit is reduced by the excess of the corporation's net long-term capital gains over net short-term capital losses for the taxable year minus the corporation's income taxes attributable to such excess. The reason for that reduction is that in determining accumulated taxable income, the taxable income is reduced by the same amount [\$ $535(\mathrm{~b})(6)]$, which is thereby made available for the reasonable needs of the business; if no reduction were made in the credit, the capital gains would, in effect, net a double deduction.

68. INT. REv. CODE of $1954, \S 535$ (c)(2). For a more thorough analysis of the accumulated earnings tax, see B. BITTKER \& J. EusTiCE, supra note 13, at 209-38; Faber, Practitioner's Guide to Defending a 531 Case: Theory and Practice, $27 \mathrm{~J}$. TAxatron 274 (1967).

69. Because of the presumption in $\$ 539$ (a) that accumulations beyond the reasonable needs of the business demonstrate that the corporation had the proscribed purpose, the parties have usually litigated only the business purpose question, and there have been few attempts to rebut the presumption. For a thorough discussion of the application of the "reasonable needs of the business" test to corporate accumulations related to a stock redemption, see Herwitz, Stock Redemptions and the Accumulated Earnings Tax, 74 HARv. L. REv. 866 (1961).

70. 393 U.S. 297 (1969). See also Commissioner v. Shaw-Walker Co., 393 U.S. 478, vacating 390 F.2d 205 (6th Cir.), remanded to T.C., 24 Am. Fed. Tax R.2d 5154 (6th 
refuge is the business needs test, ${ }^{71}$ since under the available credit, the accumulated earnings surtax will not be imposed on accumulations that do not exceed the reasonable needs of the business, irrespective of the motive for those accumulations. ${ }^{72}$ Although the statute restricts the credit to accumulations "retained for the reasonable needs of the business," 73 it appears that the credit will be granted for accumulations that are not in excess of the reasonable needs of the business even if the actual purpose of the accumulations was the proscribed one. The Commissioner has not yet contended otherwise.

If a buy-out is funded by means of a reserve, then an annual addition to that reserve will probably cause the imposition of the accumulated earnings tax to the extent that the earnings and profits accumulated in that year exceed those reasonably needed for the business. ${ }^{7 *}$ There are two separate issues here: (1) whether accumulations in anticipation of a stock redemption are within the reasonable needs of the business, and (2) if not, whether the accumulations are nonetheless exempt from the surtax because not made for the proscribed purpose. ${ }^{7 \tau}$

The business needs test provided by the credit established in section 535 refers to the business needs of only the corporation. ${ }^{76}$ In Pelton Steel Casting Company, 77 the accumulated earnings tax was imposed when income of the corporation was accumulated in order to redeem the stock of two shareholders who owned eighty per cent of the corporation's outstanding stock. A number of courts, however, have held that accumulations for the purpose of redeeming a shareholder's stock may qualify as a reasonable need of the business. ${ }^{78}$ In Emeloid Company v. Commissioner, ${ }^{79}$ the court held that

Cir. 1969). One of the bases for the remand to the Tax Court was for a determination, in accordance with Donruss, of whether or not the corporation had the proscribed purpose.

71. See Altman \& Muchin, Supreme Court's Donruss Decision Calls for a Shift in Tactics in 531 Area, $30 \mathrm{~J}$. TAXATION 202 (1969).

72. INT. REv. CoDE of 1954, $\$ 535$ (c)(1) grants a credit for amounts accumulated for the reasonable needs of the business. See Magic Mart, Inc., 51 T.C. 775 (1969), result acq., 1969 INT. REv. BuLL. No. 33, at 7.

73. INT. REv. CODE of 1954, $\$ 535$ (c)(1).

74. See text accompanying notes 65-68 supra. See also Herwitz, supra note 69 .

75. See Polasky, Planning for the Disposition of a Substantial Interest in a Closely Held Business (pt. III), 46 IowA L. REv. 516, 541-46 (1961).

76. Youngs Rubber Corp., 31 P-H Tax Ct. Mem. I 62,300 (1962), affd. per curiam, 331 F.2d 12 (2d Cir. 1964).

77. 28 T.C. 153 (1957), affd., 251 F.2d 278 (7th Cir.), cert. denied, 356 U.S. 958 (1958).

78. Mountain State Steel Foundries, Inc. v. Commissioner, 284 F.2d 737 (4th Cir. 1960), revg. 28 P-H Tax Ct. Mom. If 59,059 (1959); Gazette Publishing Co. v. Self, 103 F. 
the purchase of single premium life insurance on the life of each of the corporation's two fifty per cent shareholders, for the purpose of funding a mandatory buy-out agreement, was a business purpose, because it provided for the continuity of harmonious management after the death of one shareholder and established a reimbursement to the corporation for the loss of a key man. ${ }^{80}$ While the Emeloid case did not involve the accumulated earnings tax, ${ }^{81}$ courts and commentators alike have treated Emeloid as establishing that a stock redemption agreement may serve the needs of the corporate business for purposes of that tax. ${ }^{82}$

Thus, notwithstanding the broad language employed in Pelton Steel, it is reasonably certain that a stock redemption does serve business needs in certain circumstances. The test, apparently, is whether the redemption is for the purpose of continuing the harmonious management of the business by eliminating the stock of potentially dissident shareholders, or whether the redemption is merely for the benefit of a shareholder. If the shareholders have adverse interests as to the manner in which the corporate business should be conducted, the business purpose of the redemption is evident. Similarly, the redemption of stock of a minority shareholder is more likely to withstand attack than is the redemption of the stock of a majority shareholder, but there are circumstances in which a redemption of a majority shareholder's stock serves the needs of the corporation. ${ }^{83}$ The subjectivity of the tests for determining whether or not a stock redemption is a reasonable need of the business creates

Supp. 779 (E.D. Ark. 1952); Ted Bates \& Co., 34 P-H Tax Ct. Mem. 9 65,251 (1965); Dill Mfg. Co., 39 B.T.A. 1023 (1939), nonacq., 1939-2 Cum. BuLL. 47. Mountain State involved accumulations after the redemption for the purpose of paying notes given in exchange for redeemed stock.

79. 189 F.2d 230 (3d Cir. 1951).

80. Accumulations for the purpose of providing self-insurance against the loss of key personnel, including shareholder employees, were sustained in Bradford-Robinson Printing Co. v. United States, 1 Am. Fed. Tax R.2d 1278 (D. Colo. 1957).

81. Emeloid involved a claim for an excess profits tax credit for borrowed investment capital. The question was whether or not a loan made for the purpose of paying an insurance premium was made for a business purpose so that it qualified as borrowed investment capital.

82. Mountain State Steel Foundries, Inc. v. Commissioner, 284 F.2d 737, 745 (4th Cir. 1960), revg. 28 P-H Tax Ct. Mem. I 59,059 (1959); Ted Bates \& Co., 34 P-H Tax Ct. Mem. If 65,251, at 65-1495 n.9 (1965); Faber Cement Block Co., 50 T.C. 317, 335 (1968), acq., 1969 INT. Rev. Bull. No. 2, at 6; Herwitz, supra note 69; Polasky, supra note 75, at 541 . Additional cases, which did not involve the accumulated earnings tax, suggest that a stock purchase may serve the corporation's business needs. Sanders $v$. Fox, 253 F.2d 855 (10th Cir. 1958); Prunier v. Commissioner, 248 F.2d 818 (1st Cir. 1957).

83. See Herwitz, supra note 69 , at 909-19. 
uncertainties, and the risk that the surtax will be imposed should be recognized. Nevertheless, in some circumstances, an accumulation of corporate earnings will be advantageous even if the surtax is

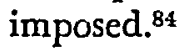

Even if an accumulation in anticipation of a stock redemption does not satisfy the business needs test, the surtax may be deemed inapplicable on the ground that the accumulation was not made for the purpose of avoiding the income tax of a shareholder.$^{85}$ If a projected redemption is likely to qualify under section 303 of the Code for exclusion from dividend treatment, it is arguable ${ }^{86}$ that accumulations for the purpose of effecting that redemption are not for the proscribed purpose, but rather are pursuant to a congressionally approved policy to permit and even to encourage the use of corporate assets to satisfy a deceased shareholder's tax liabilities and other death costs. It would be anomalous to encourage a corporation to redeem the stock of a deceased shareholder, and at the same time to deter it from accumulating the funds needed for the redemption. Since Congress has clearly encouraged redemptions to the extent of tax liabilities and death costs, funds accumulated for that purpose should be immune from the additional tax imposed by section 531. Donruss ${ }^{87}$ should not be read to require application of that tax to funds held for a congressionally approved purpose. Three cases, ${ }^{88}$ however, have held that an accumulation in anticipation of a section 303 redemption is not a reasonable need of the business. But the opinions in those cases do not attempt to reconcile their holdings with the rationale of section 303, nor do they discuss whether or not the corporation was availed of for the proscribed purpose. Indeed, there is language in another case, Mountain State Steel Foundries, Incorporated v. Commissioner, ${ }^{89}$ suggesting that the

84. If the shareholders are in high income tax brackets and funds can be withdrawn from the corporation only as dividends, the surtax on accumulations plus the ultimate cost of withdrawing funds at capital gains rates on liquidation-or at no tax cost if they are withdrawn after a shareholder's death-may be substantially less than the cost of withdrawing the funds as dividends.

85. As previously noted, it is the existence or absence of the proscribed purpose that is crucial to determining whether the accumulated earnings surtax is applicable. INr. REv. CODE of 1954, \$ 532(a); see text accompanying notes 61-73 supra.

86. This argument was suggested to the author by Mr. Lawrence Robinson in a research paper prepared by the latter.

87. See text accompanying note 70 supra.

88. Dickman Lumber Co. v. United States, 15 Am. Fed. Tax R.2d 27 (D. Wash. 1964), affd., 355 F.2d 670 (9th Cir. 1966); The Kirlin Co., 33 P-H Tax Ct. Mem. If 64,260 (1964), affd. per curiam, 361 F.2d 818 (6th Cir. 1966); Youngs Rubber Corp., 31 P-H Tax Ct. Mem. I 62,300 (1962), affd. per curiam, 331 F.2d 12 (6th Cir. 1964). 89. 284 F.2d 737 (4th Cir. 1960). 
surtax should not be imposed when section 303 is applicable. The court said:

Among other things, [Congress] specifically provided that a partial redemption of the shares held by an estate would be treated as a sale, not as a distribution of earnings, if the amount of the distribution did not exceed the estate's liabilities for estate and inheritance taxes, interest and funeral and administrative expenses. When Congress specifically provided favorable tax treatment for such transactions and sought to encourage them to facilitate the administration of estates, it hardly could have intended to penalize the corporation for doing the favored act. ${ }^{90}$

Thus, while there is little precedent to comfort the taxpayer at this date, the issue has not yet been adequately discussed by the courts, and if attention were focused on the purpose of the accumulation rather than on the business needs, it is possible that the present trend would be reversed.

Nevertheless, a judicially created exception to section 531 may be necessary for the success of such a contention, and an anticipated exception-no matter how inherently sound-to an established rule should not form the basis of any plan. Until there is more support for the argument advanced herein, the planner should rely only upon the credit granted to accumulations for the reasonable needs of the business. Of course, if litigation has already arisen as to the application of the surtax, the above argument might be useful.

But even if it is established that accumulations fulfill a business need or that an exception to section 531 is warranted, such accumulations may frustrate the congressional policy of eliminating the use of a corporation as an "incorporated pocketbook." If a corporation accumulates assets to redeem its stock, the net worth of the corporation will increase, so that the value of its stock-and consequently the cost of redemption-will rise proportionately. The resulting increase in the amount of the corporation's liability to redeem its stock will justify additional accumulations which in turn will further increase the redemption price and thereby justify even greater accumulations. This potential spiralling effect weighs against permitting any accumulations for the purpose of redemption. In the usual case, however, the accumulations do not rise in such a manner, because the corporation generally establishes a reserve only for a portion of the purchase price. Thus, a reasonable solution to this dilemma is to permit accumulations for redemption purposes when that fulfills corporate objectives, but to preclude accumulations for

90. 284 F.2d at 745 . 
that part of the redemption value of the stock which is attributable to the corporation's funded reserve. This issue has not yet been resolved and, in any event, does not become pertinent until the prior question as to taxability of accumulations has been resolved.

\section{Life Insurance Funding}

A common means of funding an entity buy-out plan is the purchase by the corporation of life insurance policies on the lives of its shareholders. ${ }^{11}$ The proceeds of the policies may be made payable to the corporation upon the death of a shareholder, and the corporation may then use the proceeds to redeem the decedent's shares of stock. As a preferable method, however, the policies may be held by a trustee who will collect the proceeds on the death of the insured, purchase the decedent's shares of stock, surrender the purchased shares to the corporation, and distribute the insurance proceeds to the decedent's estate or beneficiary. Indeed, in some circumstances, the shareholders' stock may be held in escrow by the trustee so that there is no risk of a default by the estate of a deceased shareholder. In the interest of caution, however, the stock of a subchapter $S$ corporation should not be placed in escrow, lest that terminate the subchapter $\mathrm{S}$ election. A third possibility is to make the insurance proceeds payable directly to a person or fiduciary appointed by the insured, and to make that payment subject to the conditions that the insured's stock be surrendered to the corporation and that the insurance proceeds be credited against the purchase price of the surrendered stock. The advantage of this latter method, which is rarely employed, is that it permits the recipients of the insurance proceeds to elect among the settlement options provided by the policy.

Life insurance funding is available only when the shareholders are insurable. Moreover, if one or more shareholders are given a high risk rating, the insurance costs may be prohibitive. This diffculty can be overcome if the uninsurable or high-risk shareholder already owns life insurance policies which he is willing to sell to the corporation for their cash surrender value, ${ }^{92}$ but that situation is atypical.

91. See Note, The Use of Life Insurance to Fund Agreements Providing for Disposition of a Business Interest at Death, 71 HARv. L. REv. 687 (1958).

92. If the shareholder sells the policy to the corporation for an amount greater than his net premium cost (total aggregate premiums paid less dividends), the difference will constitute income to the shareholder, and may well be characterized as ordinary income. Roff v. Commissioner, 304 F.2d 450 (3d Cir. 1962), affg. 36 T.C. 818 (1961); Edwin A. Gallan, 32 P-H Tax Ct. Mem. 963,167 (1963); Bolling Jones, Jr., 39 T.C. 404 
If life insurance funding is used for a buy-out, there are a number of considerations which must be kept in mind. Various tax consequences-involving income tax, estate tax, and the accumulated earnings tax-are associated with paying premiums, holding insurance policies, and collecting proceeds. The settlement options available to the beneficiary of a deceased shareholder should also be considered.

a. Tax consequences. In the first place, the corporation is not allowed an income tax deduction for the payment of insurance premiums. Section 264(a)(1) disallows any income tax deduction for payment of premiums on a life insurance policy covering the life of a person financially interested in the trade or business conducted by the corporation, when the corporation is directly or indirectly a beneficiary of the policy. Since the proceeds of the insurance acquired under a buy-out plan are used in place of other corporate funds as consideration for the corporation's redemption of its stock, the corporation is at least an indirect beneficiary; consequently, no income tax deduction is allowed.

Nevertheless, there will not be adverse income tax consequences to the insured when the corporation pays the premiums. Although there was once some question on this matter, it is now settled that a corporation's payment of premiums on policies insuring the life of a shareholder will not be included in the gross income of the shareholder when the corporation has substantial ownership rights in the policy, if either (1) the corporation is the beneficiary of the policy, or (2) a trustee or other party is the beneficiary and the distribution of the proceeds of the policy is conditioned upon the surrender of the insured's stock. ${ }^{93}$

Moreover, the income tax impact of the payment of premiums on a corporation's earnings and profits is not likely to be great. "Earnings and profits" is a term of art employed exclusively in corporate taxation. The earnings and profits of a corporation are the measuring rod for determining whether or not corporate distributions to shareholders constitute dividends and are therefore taxed as ordinary income. ${ }^{94}$ Earnings and profits may also be a significant

(1962). The sale to the corporation will not cause the proceeds of the insurance to be included in the corporation's gross income when the policy matures. INT. REv. CODE of 1954, §§ 101(a)(1), (2)(B).

93. Sanders v. Fox, 253 F.2d 855 (10th Cir. 1958); Prunier v. Commissioner, 248 F.2d 818 (1st Cir. 1957); Casale v. Commissioner, 247 F.2d 440 (2d Cir. 1957); Rev. Rul. 59-184, 1959-1 CuM. BuLx. 65.

94. INT. REV. CODE of 1954, $\$ \$ 301$ (c)(1), $316(a)$. 
factor in determining the tax consequences of some liquidations, ${ }^{95}$ and, as indicated above, ${ }^{98}$ may be relevant in determining the applicability of the accumulated earnings tax. Basically, the earnings and profits refer to the assets of the corporation which are available for distribution to shareholders without impairing capital. The term is not specifically defined anywhere in the Code, although section 312 and the regulations thereunder give numerous examples concerning the manner in which the size of a corporation's earnings and profits is determined..$^{97}$

The earnings and profits concept is analogous to that of earned surplus, and the two quantities are often virtually identical. It could be a disastrous mistake, however, to assume that they are necessarily identical for any given corporation, for there are adjustments made to one that are not made to the other. The distribution of stock dividends, for example, will reduce earned surplus but, except in the unusual case of a taxable stock dividend, ${ }^{98}$ will have no effect on the corporation's earnings and profits. Similarly, the capitalization of earned surplus by other means will not reduce earnings . and profits.

If a corporation owns a life insurance policy, the firm's earnings and profits will be reduced by the excess of the amount of premiums paid over the increase in the policy's cash surrender value..$^{99}$ It is unsettled, however, whether the entire increase in the policy's value is taken into account or only the increase caused by the payment of such premiums. The rationale for this rule is that the portion of a premium payment which increases the policy's cash surrender value

95. INT. REv. Code of 1954, §§ 333(e), (f).

96. See text accompanying note 63 supra.

97. For a discussion of the determination of earnings and profits, see D. KAHN, supra note 1, ch. I; Zarky \&: Biblin, The Role of Earnings and Profits in the Tax Law, U. So. CAI. 1966 TAX INST. 145.

98. INT. REv. CODE of $1954, \& 305$ provides that stock dividends are usually not taxable and describes the only two situations in which they are taxed. Recently promulgated regulations, however, have sought to expand the taxation of stock dividends. Section 421 of the proposed Tax Reform Act of 1969 (H.R. 13270, 91st Cong., Ist Sess.), if adopted, would expand the taxation of stock dividends even further. At this writing, the Bill has passed the House and is pending in the Senate.

99. One commentator has written that he knows of a private suling that so held. Katcher, What Is Meant by Earnings and Profits?, 18 N.Y.U. INSTrTure ON FEDERAL TAxation 235, 296 n.10 (1960). Zarky \& Biblin, The Role of Earnings and Profits in the Tax Law, 18 U.S.C. TAX INSTrTUTE 145, 152 (1966), state that earnings and profits are reduced by the total amount of the premiums paid and are increased by the total annual increment in cash surrender value; they rely on a stipulation between the Service and a taxpayer permitting the reduction [Shellabarger Grain Prods., 2 T.C. 75, 81 (1943)] and on a ruling (Rev. Rul. 55-257, 1955-1 Cum. BuLr. 428) that increments in cash surrender value may be added to accumulated earnings and profits for the purpose of computing equity invested capital under the excess profits tax provisions. 
has not been expended by the corporation but has merely been ex. changed for an asset of equal value.

This rule makes the accumulated earnings tax considerations of life insurance funding important. The portion of the premium that is reflected in the policy's cash value is treated as an investment; therefore, if the corporation has a substantial equity in the policy, the presence of that equity and the failure to reduce earnings and profits by the full amount of the premium payments may cause the corporation's earnings and profits to accumulate beyond the reasonable needs of the business. ${ }^{100}$ The corporation's defenses to an attempted imposition of the surtax for accumulations in anticipation of a stock redemption ${ }^{101}$ are equally applicable when life insurance is employed as the means of funding. Thus, the corporation must demonstrate that the stock redemption plan serves the needs of the business, that the insurance protects the corporation from the loss of a key man, or, possibly, that because of the interplay of sections 303 and 531, the accumulations reflected in the insurance policies are not for the proscribed purpose.

If the corporation uses term life insurance ${ }^{102}$ to fund the redemption plan, it avoids accumulated earnings problems insofar as the insurance policy is concerned. Since term insurance policies have no cash surrender value, the full amount of the premiums paid reduces the corporation's earnings and profits, and consequently the corporation's purchase of term insurance will not contribute to its accumulations. In most circumstances, however, term insurance will not solve the corporation's surtax problems. Term insurance is useful to provide a level amount of insurance for a short period of time or a declining amount of insurance for a longer period; but the cost of maintaining a level amount of term insurance for a substantial period of time will normally be prohibitive. ${ }^{103}$ If the corporation purchases declining term insurance, ${ }^{104}$ the dollar amount

100. INT. REv. CODE of 1954, $\$ 533($ a) creates a presumption that a corporation possessed the proscribed purpose when its earnings and profits are accumulated beyond reasonable business needs.

101. See notes 60-82 supra and accompanying text.

102. "Term life insurance" is pure risk insurance-the owner purchases insurance against the risk that the insured will die during the period of coverage, and no part of the premiums constitutes an equity of investment. As the insured ages, the risk of his death in any period of coverage becomes greater and the insurance premium for a fixed amount of coverage increases correspondingly.

103. For a defense of using pure term insurance for a substantial period of coverage, see J. Pawlick, How to Avoid Being Overcharged by Your Life INSURANce Salessin (1968).

104. "Declining term insurance" is term insurance of such a nature that the annual premium payments remain level or nearly so and that the amount of proceeds payable 
of insurance proceeds payable on the insured's death will be reduced each year, but the corporation's dollar obligation under its stock redemption agreement will not usually decline. Indeed, the purchase price of the stock will often increase if the corporation's business is successful. Therefore, it is customary to complement declining term insurance funding with an investment program which establishes a funded reserve, so that the value and amount of the investments will increase as the insurance declines. This again raises the specter of the accumulated earnings surtax, and, insofar as that is concerned, term insurance does not offer any advantages over ordinary life insurance. Nevertheless, for reasons discussed hereafter, ${ }^{105}$ term insurance is often the best available funding method.

Although receipt of the proceeds of a life insurance policy will increase the corporation's earnings and profits, ${ }^{106}$ there will be no surtax problems if the proceeds are paid out in redemption of the decedent's stock in the same taxable year. But even when the proceeds cannot be distributed that promptly, there will still be no surtax problems as long as the corporation has a contractual obligation to distribute the proceeds in redemption of the decendent's stock within a reasonably short period of time. ${ }^{107}$ There may, however, be an adverse consequence, since the corporation, after receiving the insurance proceeds and redeeming the stock, could realize a net increase in earnings and profits. But in most instances that will not be a serious risk and will involve small amounts. The Service has ruled ${ }^{108}$ that when a corporation receives proceeds from a life insurance policy, its earnings and profits are increased by the excess of those proceeds over the aggregate amount of premiums previously paid. Presumably, the ruling is grounded on the premise that, to the extent of premiums paid, the insurance proceeds are a return of the corporation's capital, and normally a return of capital does not affect earnings and profits. However, the soundness of this ruling is doubtful. At the time of payment, a portion of the premiums reduced earnings and profits, ${ }^{100}$ and consequently the re-

on the insured's death is reduced annually or at other stated periods. Thus, while the insurance premium "rate" increases, the coverage is reduced so that the amount of premium payable for the policy remains constant.

105. See text accompanying notes 157-66 infra.

106. See text accompanying note 108 infra.

107. Cf. Mountain State Steel Foundries, Inc. v. Commissioner, 284 F.2d 737 (4th Cir. 1960).

108. Rev. Rul. 54-290, 1954-1 Cum. BuLI. 114. See also Cummings v. Commissioner, 73 F.2d 477 (1st Cir. 1934).

109. See text accompanying notes 99-103 supra. 
capture of that portion of the premium payments should be restored to the corporation's earnings and profits. Moreover, the difference between an annual premium payment and the increment in cash surrender value caused by that payment is largely attributable to the pure insurance risk that the insured might die within that policy year.110 The consideration for that portion of the premium-one year's risk coverage-is consumed in the year for which the premium is paid, and in no sense is that portion of the premium returned to the corporation's capital by its collection of the insurance proceeds. Nevertheless, until the Service's ruling is revoked, a taxpayer is surely entitled to follow it.

When a redemption of stock constitutes a section 301 distribution, because, for example, the redemption is essentially equivalent to a dividend, the effect of the distribution on the corporation's earnings and profits is determined in the same manner as a distribution to a shareholder which is not made in redemption of stock. ${ }^{111}$ If the redemption constitutes a purchase of a shareholder's stock under section 302(a), or a partial liquidation under section 331(a)(2), the distribution in redemption will reduce earnings and profits to the extent that the distribution is not properly chargeable to capital account. ${ }^{112}$ The correct method for computing the amount of distribution which is properly chargeable to capital account is unsettled. The unresolved questions include: (1) whether the corporation's capital account is to be determined by the fair market value of property and services given to the corporation in payment for its stock or merely by the tax basis of the property given to the corporation; (2) the effect of the corporation's having several classes of stock with different rights; and (3) whether the amount of distribution which reduces earnings and profits is limited to the distributee's

110. Part of the premium is attributable to costs (including commissions), but, except for the first few annual payments, costs constitute only a small portion of such a premium.

111. The earnings and profits of the corporation are reduced by the amount of cash distributed plus the adjusted basis to the corporation of property distributed in kind. INr. REV. CoDE of $1954, \S 312$ (a). This reduction is subject to certain modifications when liabilities are transferred to the shareholder or when the distributing corporation recognizes gain on the distribution of its assets. INT. REv. CoDE of 1954, \& \$12(c).

112. INT. REv. CODE of 1954, § 312(e); see Edelstein \& Korbel, The Impact of Redemption and Liquidation Distributions on Earnings and Profits: Tax Accounting Aberations Under $\S 312(e), 20 \mathrm{TAx}$ L. Rev. 479 (1965). A redemption may appear to qualify as a purchase under the auspices of an agreement filed pursuant to $\$ 302$ (c) and may subsequently be treated as a dividend on the ground that the distributec acquired an interest in the corporation within the ten-year period. It is uncertain whether the change in earnings and profits caused by the loss of $\$ 302$ (c) treatment will be prospective from the date the distributee acquired the prohibited interest or whether the change will be imposed retroactively. 
ratable share of the corporation's earnings and profits, ${ }^{113}$ or instead is an amount equal to the difference between the amount received by the distributee and the distributee's ratable share of the corporation's capital account. 114 To understand the significance of the third question, the following hypothetical may be useful.

III-B-I. $A$ and $B$ formed the $X$ Corporation and each contributed $\$ 10,000$ cash for one hundred shares of the stock of $X$. After two years of operation, $X$ had accumulated earnings and profits of $\$ 15,000$, and the fair market value of $\mathrm{X}$ was $\$ 50,000$. $\mathrm{X}$ then redeemed $A$ 's one hundred shares of stock for $\$ 25,000$. If the reduction in earnings and profits of $X$ were limited to $A$ 's ratable share of the earnings and profits, then the amount of reduction would be $\$ 7,500(50 \% \times$ $\$ 15,000)$. However, if the reduction in earnings and profits is determined by the difference between the amount distributed to $A$ $(\$ 25,000)$ and $A$ 's ratable share of the capital account $(50 \% \times$ $\$ 20,000=\$ 10,000)$, then the $\$ 15,000$ earnings and profits would be reduced to zero. ${ }^{115}$

The amount of reduction in earnings and profits caused by a stock redemption will almost always be different from the amount of increment to earnings and profits caused by the receipt of life insurance proceeds, since the two figures are derived from unrelated sources. If the increment to earnings and profits from the insurance proceeds exceeds the reduction caused by the redemption, a net effect of the entity purchase-viewing the collection of the insurance and the redemption of the stock as a single integrated transactionis to increase the corporation's earnings and profits. ${ }^{116}$ But a corporation is permitted to reduce its earnings and profits by a portion of the premiums paid for insurance; and since the reduction to earnings and profits previously enjoyed by the corporation is not restored upon the collection of the insurance proceeds, ${ }^{117}$ the total impact on the corporation's earnings and profits usually will not be significant. Indeed, in some cases, the total reduction to earnings and profits caused by the payment of premiums and the stock redemption may exceed the increment caused by receipt of the insur-

113. See Woodward Inv, Co., 46 B.T.A. 648 (1942), acq., 1942-2 Cum. Bul.. 20.

114. See Helvering v. Jarvis, 123 F.2d 742 (4th Cir. 1941). See also G.C.M. 23460, 1942-2 Cuar. BuLl. 190, in which the Service contends that Jarvis is reconcilable with Woodward Inv. Co., B.T.A. 648 (1942), acq., 1942-2 Cum. BuLl. 20.

115. B. Bittkfr \&: J. Eustice, supra note $13, \S 7.85$, at 328-25.

116. A net increase in earnings and profits could cause adverse tax consequences either under the accumulated earnings tax provisions or by a characterization of subsequent corporate distributions to shareholders as dividends.

117. Rev. Rul. 54-230, 1954-1 Cum, BuL.. 114. 
ance proceeds, and the resulting net reduction is something of a windfall.

In most cases, the primary tax effect to the corporation of the receipt of insurance proceeds for a redemption will be the result of the effect on earnings and profits, because the proceeds of life insurance are ordinarily excluded from the gross income of the recipient. ${ }^{118}$ An important exception to this exclusion is the so-called "transfer-for-value rule": when a life insurance policy is transferred for consideration prior to maturity, the transferee will recognize as gross income the excess of the proceeds of such insurance over the sum of the consideration paid by the transferee plus premiums subsequently paid by him. ${ }^{110}$ However, there are several exceptions to the transfer-for-value rule, one of which excludes from income insurance proceeds payable to a corporate transferee when the insured is either a shareholder or an officer of the corporation. ${ }^{120}$ Thus, if the corporation purchases a policy from the insured for valuable consideration, ${ }^{121}$ the insurance proceeds received by the corporation on maturity will be excluded from the corporation's gross income. The transfer-for-value rule may create difficulties when insurance funding is used for a cross-purchase agreement, ${ }^{122}$ and therefore one of the advantages of the entity purchase is the avoidance of that rule.

The tax consequences to the corporation are not the only tax considerations relevant in using life insurance funding for a buyout. There are also potential tax difficulties for the estate of a decedent-difficulties which inhere in the nature of insurance funding. One significant danger arises from the inevitable consequence that when a corporation is the beneficiary of an insurance policy, the receipt of the proceeds of that policy will increase the net worth of the corporation so that the value of the outstanding shares of the corporation's stock will be proportionately increased. The resulting increase in the value of the decedent's stock will normally be reflected in the stock's estate tax valuation. ${ }^{123}$ But this increase in the estate tax value of the decedent's stock can be finessed if the buy-

118. INT. REV. CoDE of 1954, § 101(a)(1).

119. INT. REV. CODE of 1954, § 101(a)(2).

120. INT. REv. CODE of 1954, § 101(a)(2)(B); see note 231 infra.

121. The corporation might have purchased the policy from its shareholder because the shareholder was uninsurable at the time the redemption plan was adopted or simply because the annual premium on an older policy is smaller.

122. See text accompanying notes 231-33 infra.

123. Annie S. Kennedy, 4 B.T.A. 330 (1926). See also Newell v. Commissioner, 66 F.2d 103 (7th Cir. 1933). In effect, then, a portion of the insurance proceeds is reflected in decedent's gross estate for estate tax purposes, 
out agreement establishes a price for the decedent's stock according to a formula or figure that does not include the increment in value caused by the collection of the insurance proceeds, and if the redemption price of the stock qualifies as determinative of the estate tax value of the stock. ${ }^{124}$ It is arguable, although the Service has not yet raised the issue, that when the price established in the buy-out agreement expressly excludes life insurance proceeds, the established price is not bona fide and therefore is not determinative of the estate tax value. Nevertheless, in most circumstances, the exclusion of insurance proceeds should not render the redemption price unreasonable.

The estate tax provisions of the Code also present a danger that proceeds from an insurance policy owned by the corporation will be included in the estate of a deceased shareholder. This danger will arise primarily from the inadvertance of a shareholderor his estate planner-and can be easily avoided with careful planning. When an insured dies possessing incidents of ownership in a policy on his life, whether such incidents were exercisable alone or in conjunction with any other person, the full amount of the insurance proceeds are included in the insured's gross estate for estate tax purposes. ${ }^{125}$ Incidents of ownership include the right to change the beneficiary of the policy, the right to borrow from the insurer against the cash surrender value of the policy, and the power to surrender or cancel the policy. ${ }^{126}$ The regulations provide that even if the incidents of ownership possessed by an insured are held in a solely fiduciary capacity-for example, as a trustee with no beneficial interest in the trust-the insurance proceeds will nonetheless be included in his estate. ${ }^{127}$ Thus, if a

124. For the position of the Government as to when the price established in the buy-out agreement is determinative of the stock's estate tax value, see Treas. Reg. \$ 20.2031-2(h) (1958); Rev. Rul. 59-60, \& 8, 1959-1 Cum. Bull. 237, 243-44. See also text accompanying notes 8-12 supra.

125. INT. REv. CODE of $1954, \S 2042(2)$. Insurance proceeds will also be included in a decedent's gross estate if they are payable to the insured's executor in that capacity, without regard to the possession of incidents of ownership. INT. REv. CODE of 1954, $\$ 2012(1)$. Mloreover, the insured's possession of certain incidents of ownership, such as a power to change the beneficiary, is likely to cause adverse income tax consequences in that the premiums paid by the corporation may be treated as constructive dividends to the insured shareholder. See note 93 supra; Abrams, Tax Planning for Agreements Disposing of a Shareholder's Closely Held Stock at Death, 57 GEO. L.J. 1211, 1223 (1969).

126. Treas. Reg. \& 20.2042-1(c)(2) (1958).

127. Treas. Reg. $\S 20.2042-1$ (c)(4) (1958). In Estate of Harry R. Freuhauf, 50 T.C. 915 (1968), appeal docketed, No. 19,535, 6th Cir., April 21, 1969, the majority of the Tax Court held that incidents of ownership held by an insured in a fiduciary capacity were sufficient to trigger $\$ 2042$ and thereby to cause inclusion of the proceeds in the insured's estate. However, four of the Tax Court judges, while concurring with the 
deceased shareholder dies possessing incidents of ownership in policies on his life which are held by the corporation, the full amount of the proceeds of those policies will be included in his gross estate. ${ }^{128}$ When he is an officer or director of the corporation, it is arguable that he, in conjunction with the other officers or directors, possesses incidents of ownership, such as the power to change beneficiaries or to borrow against the policy. The possession of such powers, even though exercisable only with the consent of others, could cause the inclusion of the insurance proceeds in the insured's estate. ${ }^{129}$ The regulations provide that if a corporation is owned solely by one shareholder, its power to change the beneficiary of a policy on the shareholder's life is deemed an incident of ownership belonging to that shareholder..$^{130}$ It is possible that this "attribution" of incidents of ownership may apply also to a shareholder who owns less than one hundred per cent of the corporation, ${ }^{131}$ particularly if he serves as an officer or director of the company. Although there appear to be no cases in which incidents of ownership have been found in an insured solely by virtue of his position as a director or officer of the corporation which owns the policy, the danger remains that the Service will raise that issue in future cases. ${ }^{132}$ Accordingly, the insured should make certain that he is excluded from participating in any decisions concerning the insurance on his life, regardless of the capacity in which he would otherwise participate.

When an individual dies possessing incidents of ownership in life insurance held by a corporation, the insurance proceeds are included in his gross estate, even if the estate is obligated to surrender the decedent's stock in order to obtain those proceeds. In the latter event, however, in order to avoid double taxation, the value of the decedent's stock for estate tax purposes is then reduced by the amount of insurance proceeds to be applied against the redemp-

result reached, stated that the rule of the case should be restricted to narrower grounds in conformity with the facts-the insured was not only the trustee of the insurance trust, but he was also an income beneficiary, and his power to surrender the policies and to reinvest the proceeds could affect his income interest.

128. Hall v. Wheeler, 174 F. Supp. 418 (D. Me. 1959); Estate of Grant H. Piggott, 32 P-H Tax Ct. Mem. 63,061 (1963).

129. See Treas. Reg. $\S \S 20.2042-1$ (c)(2), (4) (1958).

130. Treas. Reg. § 20.2042-1(c)(2) (1958). See also Cockrill v. O'Hara, P-H FederaL TAXEs: Estate \& GIFT (24 Am. Fed. Tax R.2d) I 147,402 (M.D. Tenn. May 15, 1969).

131. The mention in the regulations of only sole stockholders does raise a negative inference that the principle is limited to that class, but it is a very weak inference.

132. Cf. Landorf v. United States, 408 F.2d 461 (Ct. Cl. 1969); Estate of Bert L. Fuchs, 47 T.C. 199 (1966). 
tion price. ${ }^{133}$ But when a buy-out agreement establishes the estate tax value of a decedent's stock, exclusive of the increase in value resulting from collection of the insurance proceeds, and when the insurance proceeds are included in the decedent's gross estate because of retained incidents of ownership, the Service might well contend that there would not be a double inclusion if the full value of both the stock and the insurance proceeds were included in the decedent's gross estate, and that accordingly both should be included.134

Moreover, if a corporation used life insurance proceeds to redeem a decedent's stock, but the corporation was not obligated to use them for that purpose, there is some danger that the estate tax value of the stock will not be reduced by the insurance proceeds, even when the latter are also included in the decedent's gross estate because of retained incidents of ownership. While that would constitute a double inclusion which courts may well abhor, it would be prudent to avoid the risk.

b. Settlement options. When life insurance is used as a means of funding a stock purchase plan, the parties should consider the benefits of the several settlement options ${ }^{135}$ permitted under the policy. Such options include an interest-only or deposit option, ${ }^{130}$ a fixed period option, ${ }^{137}$ a fixed amount option, ${ }^{138}$ an annuity op-

133. E.g., Estate of Ray E. Tompkins, 13 T.C. 1054 (1949), acq., 1950-1 Cum. Bull. 5; Estate of John T.H. Mitchell, 37 B.T.A. 1 (1938), acq., 1938-1 CuM. Bull. 20. While Mitchell involved a cross-purchase agreement and Tompkins involved a cross-purchase of a partnership interest, the rationale of those cases is clearly applicable to the entity purchase as well.

134. See First Natl. Bank v. United States, 14 Am. Fed. Tax R.2d 6189 (N.D. Ga. 1964), revd. on other grounds, 358 F.2d 625 (5th Cir. 1966). The purpose of excluding the insurance proceeds in valuing the decedent's stock is to prevent an escalation of value when insurance is used in funding. See example III-B-2 infra.

135. For a helpful discussion of the available options see Dillon, Settlement Options-Their Benefits and Limitations, 57 ILL. B.J. 306 (1968).

136. Under an interest-only option or a deposit option, the insurance proceeds are left with the insurer and the benficiary receives interest thereon at a guaranteed minimum rate. Customarily, but not inevitably, an interest-only option will permit the beneficiary to withdraw all or part of the insurance proceeds on demand, and frequently the beneficiary will have the right to elect other settlement options, although the latter right may be limited to a specific time period after the insured's death (usually onc or two years).

137. Under the fixed period option, the insurance proceeds are paid out in installments over a fixed period of time. Since the policy provides a guaranteed minimum interest, the minimum amount of each payment is certain; and if the policy earns more than the minimum interest, the payment for that period is larger, but the number of payments is not increased.

138. In a fixed amount option, the amount of each periodic payment is fixed, and the minimum number of such payments is established according to the guaranteed 
tion, ${ }^{139}$ a self-and-survivor annuity option, ${ }^{140}$ a joint-and-survivor annuity option, ${ }^{141}$ an annuity option with refund features, ${ }^{142}$ an annuity option with guaranteed payments, ${ }^{143}$ and combinations of these possibilities. ${ }^{144}$ Under most of these options, proceeds which are retained by the insurer for later payment will earn interest; the minimum rate guaranteed by most policies written in the past two decades ranges from 2 to $21 / 2$ per cent, and some present policies guarantee as much as 3 per cent. At this time, however, the actual interest paid by insurers is greater than the guaranteed minimum; in fact, most policies are returning 4 to $41 / 2$ per cent interest.

If the shareholder desires to elect one of the settlement options available under the policy, or wishes to permit such an election to be made after his death, the insurance proceeds may be made payable to a trustee or, in some circumstances, made payable directly to persons named by the shareholder. In either event, the insurance payment must be conditioned on the surrender of the deceased shareholder's stock. When the recipient of the insurance proceeds is a trustee, there will usually be no difficulty in imposing that condition; the trust instrument will instruct the trustee not to distribute the proceeds to the insured's estate or legatees

minimum interest; if the policy earns more than the minimum interest, the number of payments is increased, but the dollar amount of each payment is not affected.

139. A straight annuity is the periodic payment of a fixed dollar amount during the life of the beneficiary. A variable annuity is also paid for the life of the beneficiary, but the dollar amount of the periodic payments varies according to the success of the investments. Insurance policies do not now offer variable annuities, but there are indications that they may begin offering that option in the future. But see note 149 infra.

140. A self-and-survivor annuity is the periodic payment of a fixed dollar amount to a beneficiary during his life, and, after his death, the periodic payment of another fixed dollar amount (which may be smaller than that paid to the first beneficiary, but need not be) to a second beneficiary for life.

141. A joint-and-survivor annuity is the periodic payment of a fixed dollar amount to two beneficiaries for their joint lives and to the survivor of the two beneficiaries for his life. The phrase "joint-and-survivor annuity" is often used to describe an option that is actually a self-and-survivor annuity (see note 140 supra).

142. An annuity with a refund feature is an annuity which provides that if the beneficiary dies before receiving a certain dollar amount, the difference shall be paid to the beneficiary's estate or to a third party.

143. When an annuity contains a provision for guaranteed payments, the insurer guarantees that if the annuitant should die within a stated period of time (such as five, ten, or fifteen years), the insurer will continue to make payments for the guaranteed period of the same amount that would have been payable if the annuitant were still living. These guaranteed payments can be made payable to a contingent beneficiary. Of course, if the annuitant survives the guaranteed period, the annuity payments will be made for the duration of his life.

144. These options do provide some flexibility. For example, it is possible to have a fixed-period option under which a larger periodic payment is made during the period of a child's minority and the payments are reduced when the child attains his majority. 
until the stock is surrendered. The same result can be achieved if the shareholder's stock is held in escrow by the trustee during the shareholder's life. ${ }^{145}$ When a trustee is the beneficiary of the policy and the election of a settlement option is desired, it may be necessary to obtain the prior consent of the insurance company to the trustee's election of an option, since the terms of insurance policies frequently do not permit a fiduciary to receive proceeds under a settlement option. Many insurance companies, however, upon request will amend the policy's provisions to permit such an election, and this amendment should be executed before the shareholder's death. Furthermore, the trust instrument should expressly authorize the trustee to utilize the settlement options.

When the insurance proceeds are made payable to an individual beneficiary, rather than to a trustee, and when the distribution to the individual beneficiary is conditioned on the surrender of the shareholder's stock, it would be prudent to incorporate that restriction in the designation of the beneficiary. For example, the designation of beneficiary clause might read:

To $A$ if he survives the insured and if the insurer receives written notice from the president of the $X$ Corporation, a Delaware corporation, within one year after the insured's death that all of the insured's stock of $X$ has been surrendered to $X$; and if $A$ fails to survive the insured, or if the insurer does not receive such written notice from the president of $X$ within one year after the insured's death, the proceeds shall be distributed to the $X$ Corporation.

In most circumstances, it will be preferable to name a trustee as beneficiary; but if the insurer will not permit a trustee to elect among the policy's settlement options, the policy may provide for payment to an individual beneficiary as long as the insurer agrees to accept the attendant restrictions on distribution.

While settlement options are useful in some circumstances, careful consideration should be given to other available choices. Depending upon the desired goals, a lump-sum distribution of the insurance proceeds to a trustee, either for immediate payment to a named beneficiary or to be held in trust under the terms of a

145. If the corporation has made an election under subchapter S (INT. REv. CODE of 1954, \$\$ 1371-78), the trustce should not hold a shareholder's stock since that entails some risk that the subchapter S election will be terminated. See Treas. Reg. $\$ \$ 1.1371$ 1(e) (1959), 1.1372-4(b)(3) (1959). But see A \& N Furniture \& Appliance Co. v. United States, 19 Am. Fed. Tax R.2d 1487 (S.D. Ohio 1967). While one writer has suggested that stock may be held in escrow without violating the prohibition against trustees holding subchapter S stock [Crumbley, Buy and Sell Agreements for Subchapter S Corporations, 108 TRUSTS \& ESTATES 17 (1969)], the in terrorem aspect of the risk of terminating an election is likely to deter all but the bravest from using escrow arrangements. 
trust instrument, will frequently be more desirable. The choice between using a trust arrangement or a settlement option should rest on an evaluation of the parties' goals and of the relative advantages and disadvantages of each method in light of those goals. ${ }^{145}$

Trust arrangements are far more flexible than settlement options; if the trust assets are invested wisely, the trust should produce a much higher yield than that obtained from insurance options which provide a relatively low rate of return. The trust provides better protection against the present inflationary spiral; and particularly when the beneficiaries are minor children, the flexibility of a trust may be needed. The trust vehicle, however, usually involves costs not associated with insurance, such as legal fees for creating the trust and trustee fees for administering it. If the proceeds are relatively small, ${ }^{147}$ the costs of the trust arrangement may outweigh its advantages. For example, although the fees of a professional fiduciary are determined by the size of the trust estate and the annual trust income, there is usually a minimum fee which could make a small trust uneconomical. Nevertheless, trustee fees, and perhaps some of the legal fees incurred in creating the trust, will usually be deductible for income tax purposes under section 212 of the Code; consequently, only the net expenses of the trust arrangement-the fees less the tax savings enjoyed by deducting them-should be considered.

On the other hand, the insurance options provide greater security. There is virtually no risk of loss, and a recession in the economy will have less effect on insurance than on almost any other investment. There are no direct costs for managing the insurance proceeds, and when small amounts are involved, costs can be a substantial factor. Moreover, if the beneficiary of the insurance is the surviving spouse of the insured, there may be a small tax advantage to using an insurance option: if the proceeds are payable to the surviving spouse in installments over a period of years, such as is the case in an annuity option, the interest portion of the installment payments may be exempt from federal income tax in an amount up to 1,000 dollars per year. ${ }^{148}$ While this exemption is advantageous, particularly if the surviving spouse is in a high income tax bracket, some commentators have exaggerated its use-

146. For a slightly biased, but nevertheless relevent, discussion of the circumstances in which settlement options may be useful, see Snitzer, Investment Growth Through Settlement Options, 108 Trusts \& EsTates 204 (1969).

147. In making this determination, $\$ 25,000$ is frequently named as a rule of thumb amount of demarcation.

148. INT. REv. CODE of 1954, § 101(d). 
fulness. If the spouse is in a thirty per cent income tax bracket, for example, the maximum benefit of the exemption is 300 dollars per year. There is no reason to scorn that amount, but it does not warrant distorting an entire estate plan.

Insurance companies are making considerable efforts to make settlements options more flexible; and as more such companies enter the mutual fund business, it is likely that in the not-toodistant future they will offer variable annuities. ${ }^{149}$ Consequently, the available options must be scrutinized carefully in each case and reviewed at periodic intervals, since favorable changes may occur rapidly in this area. Unless life insurance options become as flexible as trust arrangements - an unlikely event since insurance companies are not staffed to make discretionary determinations as to distributions-the trust will continue to have an advantage in that regard. But the two are not mutually exclusive; in some cases it may be desirable to split the insurance proceeds between settlement options and a trust arrangement, thereby providing both a hedge against inflation and a minimum floor of security.

When the widow of a deceased shareholder is to be the ultimate recipient of the insurance proceeds, it is desirable that any settlement option selected prior to the shareholder's death be one that will qualify for the marital deduction allowance. ${ }^{150}$ Generally, no marital deduction will be allowed for insurance proceeds which are made payable in a manner which contravenes the terminable interest rule. ${ }^{151}$ But an important exception to this rule is that a terminable interest in the insurance proceeds will qualify for the marital deduc-

149. See note 135 supra. One of the difficulties encountered by insurance companies that wish to adopt a variable annuity is that such plans will probably constitute a security and will therefore be subject to the regulations and restrictions imposed by state and federal governments on the sale of securities. See SEC v. United Benefit Life Ins. Co., 387 U.S. 202 (1967); SEC v. Variable Annuity Co., 359 U.S. 65 (1959). Some of these restrictions might be incompatible with insurance goals.

150. INT. REv. CODE of 1954, $\$ 2056$. When the insurance proceeds are paid to the widow in exchange for the decedent's stock, and when the redemption of the stock is mandatory, the property transferred from the decedent to the widow will probably be decmed the insurance proceeds rather than the stock, and the qualifications for deductibility will almost certainly be measured against those proceeds.

151. INT. REv. CoDE of 1954, $₹ 2056$ (b)(I) disallows a deduction for the transfer of property to a surviving spouse if the transfer will terminate on the lapse of time or on the occurrence or nonoccurrence of a specific event and if, by reason of such termination, an interest in the property will pass to a third party who received his interest in the property from the decedent for less than full and adequate consideration in money or money's worth. Thus, insurance proceeds payable to the widow under a joint and survivor annuity option, with the widow and her daughter as beneficiaries, will not qualify; nor will an annuity with a refund feature unless the provisions of $\S 2056(\mathrm{~b})(6)$ are satisfied, or unless the refund is payable to the estate of the surviving spouse. 
tion if the surviving spouse has the power to appoint the property to herself or to her estate and if the other conditions of section 2056 (b)(6) of the Code are satisfied. ${ }^{152}$

Additional care is necessary when dealing with redemptions under section 303 of the Code. ${ }^{153}$ While section 303 is not limited exclusively to redemptions of stock from the probate estate of a decedent, ${ }^{154}$ the regulations state that it does not apply to redemptions of stock acquired from the decedent's estate in satisfaction of a specific pecuniary bequest. ${ }^{155}$ Consequently, if the decedent's stock is to be distributed to his widow, or to a marital trust, in satisfaction of a pecuniary bequest-including a bequest defined in terms of a marital deduction pecuniary formula-and if a redemption under section 303 is contemplated, the stock should first be redeemed from the decedent's estate and then the proceeds distributed to the widow or to the marital trust.

c. Merits and disadvantages of insurance funding. When life insurance is acquired by a corporation to fund a stock purchase agreement, the receipt of the proceeds of the insurance will increase the value of the deceased shareholder's stock proportionately; and if the stock is to be redeemed at fair market value, the corporation will need sufficient liquid assets to cover the increment in value caused by the insurance. Of course, the corporation could acquire additional insurance to fund the obligation, but such additional insurance would further raise the value of the decedent's stock, and thus the corporation's dollar obligation would pyramid upward. The following example illustrates this problem:

III-B-2. The outstanding shares of the $X$ Corporation were owned equally by $A$ and $B . X$ had a net worth of $\$ 400,000$; consequently the value of each shareholder's stock was $\$ 200,000$. $X$ purchased life insurance in the amount of $\$ 200,000$ on $A$, and a like amount on $B$, in order to fund a stock redemption plan. $X$ was the beneficiary of the policies. $A$ died shortly after the insurance was acquired. After $A$ 's death and the collection of the proceeds, the net worth of $X$ was $\$ 600,000$, and the value of each shareholder's stock was $\$ 300,000$. Consequently, $X$ needed $\$ 100,000$ liquid assets in addition to the insurance proceeds to redeem $A$ 's stock. If, in anticipation of that

152. The conditions of $\S 2056(\mathrm{~b})(6)$ are discussed in Treas. Reg. $\$ 20.2056(\mathrm{~b})-6$ (1958).

153. See note 15 supra.

154. Treas. Reg. $\$ 1.303-2(f)(1955)$.

155. Treas. Reg. $\$ 1.303-2(f)(1955)$. The validity of this regulation has been questioned. Meyer, Redemption of Stock in the Close Corporation To Pay Death Taxes, N.Y.U. 27TH INST. ON FED. TAx. 401, 403-05 (1969); cf. United States v. Lake, 406 F.2d 941 (5th Cir. 1969) (construing the regulation narrowly). 
obligation, $X$ had purchased an additional $\$ 100,000$ insurance on the life of each shareholder, its net worth on $A$ 's death would have been $\$ 700,000$, and the value of $A$ 's stock $\$ 850,000$. The corporation could have funded the additional $\$ 50,000$ with insurance also, but that would further raise the net worth, requiring still more insurance to fund the purchase. Obviously, such an arrangement is self-defeating; the principal beneficiaries are the insurance company and its agents.

The escalation of insurance coverage can be finessed by using a stock redemption agreement to establish a price for the shareholder's stock in such a manner that the insurance proceeds are omitted from the valuation formula. ${ }^{156}$ The principal drawback of this arrangement is that the deceased shareholder will not receive payment for the true value of his stock; thus the transaction favors those shareholders who survive:

III-B-3. The $X$ Corporation had two equal shareholders, $A$ and $B$. The corporation and the shareholders executed a stock redemption agreement under which $X$ agreed to redeem the stock of the first shareholder to die at a price equal to $50 \%$ of the net worth of the corporation exclusive of insurance proceeds. $X$ acquired insurance of $\$ 200,000$ on the life of $A$ and a like amount on $B$. When $A$ died, the net worth of the corporation, exclusive of insurance proceeds, was $\$ 400,000$, and consequently $X$ redeemed $A$ 's shares for $\$ 200,000$. However, the actual net worth of the corporation was $\$ 600,000$; therefore $A$ received $\$ 100,000$ less than the actual value of his interest.

The exclusion of the insurance proceeds from the redemption price may be justifiable if $A$ dies shortly after the insurance is purchased, since in that event the proceeds result from $A$ 's death rather than from the corporation's earnings. But even then, it might be questioned why $B$ should derive a windfall from the death of his fellow shareholder. Moreover, if $A$ 's death occurs many years after the insurance is purchased, and if the insurance used is ordinary life, a significant portion of the insurance proceeds payable on $A$ 's death represents the corporation's equity in the policy. Since that equity was derived from premiums paid from corporate earnings, the redemption agreement's forfeiture of $A$ 's interest in it is harsh. This problem can be resolved by limiting the exclusion of insurance proceeds from the purchase price to the excess of the proceeds over the cash surrender value of the policy.

156. Of course, the agreement should also be designed so that the redemption price will fix the value of the stock for estate tax purposes, and so that the deceased shareholder will not possess any incidents of ownership in the policy at his death, since that would result in the inclusion of the proceeds in his taxable estate. INT. REv. CODE of 1954, \$ 2042. See text accompanying notes 8-12, 125-34 supra. 
The above discussion, however, does not mean that a deceased shareholder derives no benefit from a plan of this kind or that such a plan should not be adopted. The decedent's estate does obtain a market for liquidating the stock promptly. But the primary advantage of the arrangement is that it permits a surviving shareholder to continue a business which otherwise might have to be liquidated. It might be suggested that few investors are so unselfishly devoted to the continuity of their businesses that they would wish to forfeit large sums of money to further that end. But at the time that the redemption agreement is executed, the identity of the surviving shareholder is a mystery, and if the forfeiture of a significant sum by the first to die is necessary for the continuance of the business, the parties may wish to gamble as to who that will be. It should be made clear to them, however, that they are gambling and that the first to die will be a financial loser. The gamble may be desirable for business reasons, but it is important that the parties recognize it for what it is and not delude themselves with a myth that a deceased shareholder will be paid the full value of his stock.

Of course, the liquidation value of a business is usually substantially less than its value as a going concern, and consequently, in some cases, the amount paid to a deceased shareholder's estate reflects in part the loss that would be suffered if the business were liquidated. In fact, the amount paid may be even more than would be possible if liquidation were necessary.

An important decision to be made with respect to insurance funding is the selection of the kind of insurance. Usually the best choice is either ordinary life or declining term insurance. ${ }^{167}$ Ordinary life insurance comprises two separate property interests: (1) a reserve (or equity) in the policy which reflects the policyholder's investment plus interest earned thereon, and (2) coverage against the risk that the insured will die during the policy period. As the equity grows larger over the years, the amount of insurance risk coverage-the difference between the face value of the policy and the equity therein-declines. Declining term ${ }^{158}$ is pure insurance; the policyholder has no equity in the policy. The amount of

157. Occasionally, group term life insurance may be used for funding. See Walker, Life Insurance from the Standpoint of the Federal Corporate and Personal Income Tax, Gift Tax and Estate Tax, U. So. CAL. 1966 TAX InstrTuTE 543, 588-93. For a recent statement of the Service's position on the effectiveness of an assignment of group term life insurance for estate tax purposes, see Rev. Rul. 69-54, 1969-6 INT. REv. BuLL. 20. See also Landorf v. United States, 408 F.2d 461 (Ct. Cl. 1969).

158. See notes 102, 104 supra. 
insurance coverage under declining term is reduced periodically. Thus, if liquid assets are to be available when a shareholder dies, it is necessary to complement declining term with a periodic investment program. The amount invested periodically could, for example, be the difference between an ordinary life premium and the smaller declining term premium.

There are several sophisticated plans for purchasing what amounts to declining term life insurance at a smaller cost than that charged for the outright purchase of such a policy. The most common technique is to purchase ordinary life insurance and each year to "borrow" from the insurer an amount equal to the policy's cash surrender value, using the "borrowed" funds as partial or full payment for the policy's premium plus the interest accrued on prior loans. This type of insurance plan is frequently referred to as "minium deposit insurance." Since the amount lent will increase each year, since the owner maintains little equity in the policy, and since the insurer will collect the loans from the insurance proceeds on maturity, the net effect of the minimum deposit insurance plan is to acquire a declining term policy-that is, the amount payable to the insured's beneficiary decreases each year when an additional loan is made. Minimum deposit insurance is used primarily by persons in high income tax brackets. The cash surrender value (a rough estimate of the owner's equity in the policy) increases each year, but the rate of increase is lower than the rate of interest payable on funds borrowed from the insurance company by the owner. The rate of increase, for example, may be $21 / 2$ per cent while the loan may bear interest of 5 per cent. Thus, the owner pays a greater amount of interest on his loans than he earns on his investment in the policy made with those borrowed funds. The increments in cash value of the policy, however, do not constitute taxable income to the owner, ${ }^{159}$ nor will they be taxed to the beneficiaries of the policy on maturity. ${ }^{160}$ If the owner is permitted to take an income tax deduction for his interest payments, the net cost of the loans may be less than the increments in the policy's value. Although section 264 of the Code prohibits the deduction of interest paid on loans incurred pursuant to a systematic borrowing plan for the purchase of life insurance or of endowment or annuity contracts, it makes several explicit exceptions. The most useful of these permits deduction of the interest if no part of any four of the

159. Theodore H. Cohen, 39 T.C. 1055 (1963).

160. INT. REV. CODE of 1954, \& 101. 
annual premiums due during the first seven years ${ }^{161}$ of the policy is paid with borrowed funds, ${ }^{162}$ and if the amount of loans made thereafter to the policy owner does not exceed the amount of premiums paid to the insurer for years subsequent to the fourth year in which the premium was paid without borrowing. ${ }^{103}$ Thus, in effect, the premiums paid for those four years must be left with the insurer and not withdrawn as loans at some subsequent date, especially not within the first seven-year period of the policy.

If a corporation-or an individual-owns a policy on the life of a shareholder and wishes to purchase additional life insurance coverage through a minimum deposit insurance plan, it may exchange its existing policy for a new one issued by the same insurer but having a greater principal sum. Its reserve in its existing policy will constitute premium payments for the new policy, and any unpaid premium due for the first four years of the new policy can be paid in cash. Since section 1035 of the Code is likely to preclude the recognition of gain on such an exchange, this arrangement can be a relatively painless method for acquiring minimum deposit insurance while complying with the requirements of section 264 for the deduction of interest payments made on subsequent loans borrowed against the policy's reserve value.

But the minimum deposit insurance plan can be advantageous even if no interest deduction is allowed. When a policy owner has a liquidity shortage, ${ }^{164}$ systematic borrowing permits him to maintain a high level of insurance coverage; and when his liquidity problems are resolved, he can pay subsequent premiums outright and perhaps repay the outstanding loans.

Although premiums on an ordinary life insurance policy will be greater than those on a declining term policy, the choice between the two should not be made on this basis alone. Premiums on an ordinary life policy represent two things--payment for insurance risk coverage and an investment in the policy-whereas premiums on a declining term policy represent only the cost of insurance. ${ }^{165}$ Normally, the money which is saved by purchasing de-

161. If there is, at any time, a substantial increase in the premium amount, the seven-year period begins anew. Treas. Reg. $\$ 1.264-4$ (d)(1) (1964).

162. INT. REv. CoDE of $1954, \S 264$ (c)(1).

163. Treas. Reg. § 1.264-4(d)(1) (1964).

164. But if a shortage is due to a substantial loss of income or to a substantial increase in financial obligations which was unforeseeable at the time the insurance con. tract was entered into, an interest deduction is permitted under an exception to the general rule. INT. REv. CoDE of 1954, § 264(c)(3); Treas. Reg. § 1.264-4(d)(3) (1964).

165. Actualiy, the pure insurance cost factor in an ordinary life premium is less than the premium for a like amount of declining term insurance. 
clining term will be invested in other markets. Hence, the decision should be made on the basis of an evaluation of investment opportunities. If the best available investment is in an insurance policy, ordinary life should be chosen; otherwise, declining term is preferable. ${ }^{100}$

Insurance provides security of both income and capital, but the rate of return is small. However, as previously noted, ${ }^{167}$ the equity in an insurance policy earns interest which is reflected in increments in cash surrender value, and that interest is not included in the policyholder's gross income for income tax purposes. ${ }^{168}$ This income tax exclusion may be an important consideration in selecting an investment. On the other hand, investments in stocks, securities, or real estate may yield a substantially greater return than insurance does, and the unrealized appreciation of such investments is not taxed. Moreover, a funded reserve may be utilized by the corporation to further its business interests. The corporation, for example, could use a funded reserve to construct a building which the corporation would occupy; on the death of a shareholder, the building could be sold or distributed in kind to the decedent's estate as part of the redemption price.

\section{Payment with Promissory Notes}

If a corporation lacks sufficient liquid assets to redeem a shareholder's stock within a few years after his death, it can use its own personal notes as partial or full payment of the redemption price. When such notes are given within the time period permitted under section 303 of the Code, ${ }^{160}$ the tax relief afforded by that section is available, even if the payments on the notes extend beyond the statutory period. ${ }^{170}$ It is important, however, that the corporation's notes do not constitute an equity interest in the corporation, because if they do, and are therefore treated as hybrid stock, the "in-

166. For an unabashed polemic against the use of ordinary life insurance rather than term insurance, see J. PAwLICK, How to AvoId BEING Overcharged BY Your Life INSURANCE SALESMAN (1968).

167. See note 159 supra and accompanying text.

168. Abram Nesbitt, II, 43 T.C. 629 (1965); Theodore H. Cohen, 39 T.C. 1055 (1963). Dividends received by a policyholder from a mutual insurance company constitute a partial refund of the premium paid by the policyholder and therefore are excluded from the policyholder's gross income. See INT. REv. CoDE of 1954, \& 316(b)(I); S.M. 5680, V.1 Cum. BuLL. 32 (1926). However, the interest earned on dividends which were recoived from a mutual insurance policy, but were left with the insurer to earn interest, is included in the policyholder's gross income. Theodore H. Cohen, 39 T.C. 1055 (1963).

169. See note 15 supra and notes 171.73 infra and accompanying text.

170. Rev. Rul. 65-289, 1965-2 Cum. Bull. 86; Rev. Rul. 67-425, 1967-2 Cum. Bull. 134. 
terest" paid on the notes cannot be deducted by the corporation on its income tax returns, and the payments made on the notes will be treated as a redemption of stock which may well cause ordinary dividend income to the recipient. If the notes represent equity interests in the corporation, payments made on these notes after the statutory period defined in section $303^{171}$ will not lie within the protective umbrella of that section.

Normally, four precautions are sufficient to avoid the characterization of notes as equity interests: (1) the debt-capital ratio should not be overbalanced in favor of debt; (2) the maturity dates of the notes should not be far removed from the date of issue, ${ }^{172}$ preferably no more than five years; ${ }^{173}$ (3) the notes should not be subordinate to the claims of creditors; and (4) the notes should bear a reasonable rate of interest. Business considerations may not permit the parties to take all of these precautions, but the precautions should be followed to the extent that they are feasible.

The use of promissory notes to redeem stock can be helpful even when section 303 is inapplicable. The corporation, for example, may issue its notes in redemption of all of a shareholder's stock; such a redemption should qualify as a purchase under section 302(b)(3) of the Code, rather than as a dividend, provided that there are no attribution problems ${ }^{174}$ and that the corporate notes are not treated as hybrid stock. If attribution exists only because stock is owned by members of the shareholder's family, that attribution can sometimes be avoided by utilizing the relief afforded by section $302(c) .{ }^{175}$

If the parties to a buy-out agreement anticipate the use of promissory notes to finance the purchase, they should provide in advance

171. The statutory period usually lasts about $41 / 2$ years after the deceased shareholder's death, but the period may be extended if an estate tax deficiency is litigated in a Tax Court proceeding. INT. REv. CODE of 1954, § 303(b)(1).

172. The Service has announced that it will not issue rulings on the applicability of $\S 302(b)$ to corporate redemptions financed by notes which are to be paid over "a long future period." Rev. Proc. 64-31, § 3.01-5(b), 1964-2 CuM. BulL. 947, 949. Presumably, that announcement will also apply to $\$ 303$ redemptions. See note 173 infra.

173. If it is necessary, and if the parties are willing to undertake the risk, the notes can be made payable for a longer period of time. In one instance, payment over a seventeen-year period was approved in a private ruling. ABA BLLL. OF THE SECTION of TAXATION 134 (Fall 1967). After the date of that ruling, however, the Service announced that ordinarily it will not rule on the tax effect of a redemption when payment is made in corporate notes payable over more than fifteen years. Rev. Proc. 69-6, § $4.01-3,1969$ INT. REv. BuLl. No. 1, at 31.

174. See note 14 supra.

175. Section $302(c)(2)$ provides that in certain clearly defined circumstances, $\$ 318$, under which stock owned by one member of a family is attributed to another family member (see note 14 supra), is inapplicable. 
for the interest that the notes will bear. ${ }^{176}$ More important, they should provide for any security which might be desired. Adequate security may not only help to prevent characterization of the notes as an equity interest, but will often be particularly useful for a shareholder who wants to minimize any financial risk to which his survivors would be subject if they hold the corporation's notes. Of course, in some situations, the net asset value of the corporation may be of such magnitude as to render that risk inconsequential, or the risk may have to be undertaken because no other means of payment is feasible. But if security is to be provided, it is preferable for the corporation to secure the notes with assets other than the redeemed stock, since a pledge of the redeemed stock may prevent the transfer of the corporation's notes from qualifying as a payment; ${ }^{177}$ the transaction may not be deemed closed when the stock is surrendered because there is a possibility that the shareholder will reacquire it on default. Whether or not that contention is sound, the Service's refusal to rule on the question promotes the avoidance of such an arrangement. If the transaction is not deemed closed when the note is issued, payments made after the statutory period will not come within section 303, and the shareholder's interest in the pledged stock may render inoperative the section 302(b) exclusions from dividend treatment on redemption. Moreover, a pledge of the redeemed stock is not a particularly valuable security device. If the corporation is unable to pay its debts, its stock is not likely to be of greater value than the defaulted notes. Finally, if the pledge of the stock constitutes a secured transaction within the coverage of article 9 of the Uniform Commercial Code, the secured party might be required to hold a public sale of the stock in order to foreclose on his lien. Such a public offering would force him to comply with federal and state security regulations, and that is a costly procedure. ${ }^{178}$

176. Interest will be imputed at a $5 \%$ rate [INT. REv. CoDE of 1954, $\$ 483$; Treas. Reg. $\$ 1.483-1$ (c)(2) (1966)], if the notes of the corporation do not bear interest of at least 4\%. Treas. Reg. $\$ 1.483-1$ (d)(2) (1966). While a redemption does not constitute an actual sale or exchange, $\$ 483$ applies to transactions that are "treated as a sale or exchange for purposes of the Code." Treas. Reg. $\S 1.483-1(b)(1)(1966)$. If the note is payable within one year after redemption, however, $\$ 483$ is not applicable [INr. REv. CODE of 1954, $\S 483(\mathrm{c})(\mathrm{l})(\mathrm{B})]$, but few notes will be payable in such a brief period.

177. Rev. Proc. 69-6, \$ 3.01-5, 1969 INr. Rev. Bull. No. 1, at 29, states that the Service will not rule on whether $\$ 302(b)$ applies to a redemption plan under which the redeemed stock is held as security or in escrow for the payment of corporate notes, and under which there is a possibility that the stock may be returned to the shareholder on default. For a discussion of this issue, see Sexton, Providing Security for the Outgoing Stockholder and Avoiding Tax Disadvantages to Selling and Remaining Stockholders, N.Y.U. 24TH INST. ON FED. TAX. 555 (1966).

178. See Mitchell, Corporate Buy-Sell Agreements and the Uniform Commercial Code, 16 MIrн. Sr. B.J. 12 (May 1967). 
Another means of safeguarding the interests of those who inherit from a deceased shareholder is to have the corporation's notes personally guaranteed by the surviving shareholders. If this is done, the corporation's subsequent payments on the notes, even though they reduce the potential secondary liability of the surviving shareholders, will normally not constitute constructive income to them because the corporation is the primary obligor, and because the shareholders are merely incidental beneficiaries of the corporation's satisfaction of its debt. ${ }^{179}$ If, however, the corporation's capacity to satisfy the obligations is extremely doubtful, its liability may be deemed a sham, and the payments made by the corporation may constitute dividend income to the shareholder-guarantors.

If the various objections to the use of corporate notes are outweighed by their desirability, then attention must be paid to the various financial and equitable limitations on a corporation's redemption of its own stock. ${ }^{180}$ In particular, there is considerable question as to when the corporation must satisfy the applicable financial requirements-when it distributes its promissory note, when it makes payments on the note, or at both times. ${ }^{181}$ According to one view, the financial limitations are applicable only when the corporation makes payments on its note and only to the extent of such payments, since the mere transfer of a corporate note does not prejudice the corporation's creditors or other stockholders. ${ }^{182}$ Under that approach, the transferee of the note must accept the risk that financial restrictions might prohibit the corporation from making payments on it. Another view would treat the transaction as closed when the note is given. ${ }^{183}$ Thus, unless the issue is settled in the controlling jurisdiction, the planner should attempt to provide for the corporation's compliance with the financial requisites at all relevant dates.

\section{Corporate Law Considerations}

The corporate laws dealing with the transfer and redemption of stock differ from state to state. Several of the underlying considerations which are uniformly applicable are discussed below, but the

179. See Murphy Logging Co. v. United States, 378 F.2d 222 (9th Cir. 1967); Princess Coals, Inc. v. United States, 239 F. Supp. 401, 411-12 (S.D. W. Va. 1965); Arthur J. Kobacker, 37 T.C. 882, 895 (1952), acq., 1964-2 Cum. Bull. 6; Rev. Rul. 59-286, 1959-2 Cum. BuLl. 103.

180. See text accompanying notes 203-08 infra.

181. See ABA Bull. of the Section of Taxation 134 (Fall 1967).

182. See, e.g., Mountain State Steel Foundaries, Inc. v. Commissioner, 284 F.2d 737 (4th Cir. 1960).

183. See ABA Bull. of the Section of Taxation 134 (Fall 1967). 
preparation of a specific entity buy-out plan must include a careful examination of the corporate laws of the appropriate jurisdiction.

A major purpose of a mandatory buy-out is to prevent a decedent's stock from falling into the hands of persons who will disrupt managerial harmony. ${ }^{181}$ For that reason, when a mandatory buy-out is arranged, the agreement should impose restrictions on a shareholder's transfer of his stock during his life. ${ }^{185}$ Moreover, a buy-out agreement will not establish the value of the decedent's stock for estate tax purposes unless there are adequate restrictions on the shareholder's right to sell the stock during his life. ${ }^{186}$ The most popular restriction on lifetime transfers is a provision granting the corporation the right of first refusal.

The extent to which restrictions can be imposed upon the transfer of stock depends upon local law. Generally, an absolute restraint on alienation, unlimited in time, is invalid; ${ }^{187}$ but reasonable restraints on transfers are permissible. ${ }^{188} \mathrm{~A}$ right of first refusal usually constitutes a reasonable restraint. ${ }^{189}$ In addition, mandatory stock purchase agreements to be implemented on death are likely to be valid in all jurisdictions. ${ }^{190}$ Although a 1928 New York Court of Appeals decision-Topken, Loring of Schwartz, Incorporated $v$. Schwartz ${ }^{191}$ - held a stock purchase agreement invalid as lacking mutuality because the corporation might not have sufficient surplus to make the purchase when the time came to acquire the stock, that decision has no continuing vitality. It is highly unlikely under present law that a court, in Nerw York or in any other jurisdiction, would hold a stock redemption agreement invalid for the reason given in

184. A mandatory buy-out agreement constitutes a restraint on transfer after the death of the shareholder.

185. These restrictions may take many forms, such as an absolute prohibition against any transfer, a requirement of obtaining the prior consent of other shareholders or directors or a percentage of them, or a "first-option" provision granting the corporation or its directors or shareholders a right of first refusal to purchase stock that a shareholder wishes to sell. 2 F. O'NeAL, Crose Corporations $\$ 7.05$ (1958) provides a list of the types of restrictions that have been imposed.

186. See note 10 supra.

187. O'Neal, Restrictions on Transfer of Stock in Closely Held Corporations: Planning and Drafting, 65 HARv. L. REv. 773, $777-78$ (1952).

188. H. Ballantine, Corporations $\$ 336$ (1946 ed.); 12 W. Fletcher, Crclopedia of the Law of Private Corporataions \$ 5453 (perm. ed. rev. repl. 1957).

189. 2 F. O'Neal, Close Corporations $\$ 7.09$ (1958).

190. Id. \$ 7.10. Of course, if the provisions of the agreement are too severe, such as when the buy-out price is extremely low, there is a risk that the agreement will be invalid [Green v. E.H. Rollins \& Sons, Inc., 22 Del. Ch. 394, 2 A.2d 249 (1938)], but otherwise there is little danger of invalidity. This is an additional reason for establishing a reasonable price for the stock.

191. 249 N.Y. 206, 163 N.E. 735 (1928). 
Schwartz. ${ }^{192}$ Indeed, the remote possibility that Schwartz might have a continuing influence on New York corporate law was terminated by statutory enactment. ${ }^{193}$

The validity of restrictions on stock transfers depends in part upon the means by which they are imposed. Such restrictions should be included both in the articles of incorporation and in a separate contractual agreement between the corporation and the shareholders. ${ }^{194}$ As an alternative in some states, the relevant restriction could be included in the bylaws. ${ }^{195}$ Furthermore, under both the Uniform Stock Transfer Act and the Uniform Commercial Code, the restrictions must be stated on the face of the share certificates. ${ }^{101}$

A restriction against all inter vivos transfers would prevent the shareholders from donating part of their stock holdings to members of their family for estate planning purposes. It may therefore be desirable to exempt gifts to a limited class of close family members, provided that the same transfer restriction is made applicable to any donee, and that the transferred stock is subject to a mandatory redemption at the donor's death. ${ }^{197}$

Self-imposed restrictions, however, are not the only limitations on the transfer of shares pertinent to a buy-out arrangement. State laws in some jurisdictions once prohibited a corporation from purchasing its own shares, and, indeed, such a prohibition still exists in

192. 2 F. O'Neal, Close Corporations \& 7.10 (1958). See Greater N.X. Carpet House, Inc. v. Herschmann, 258 App. Div. 649, 17 N.Y.S.2d 483 (1940) (enforcing a stock purchase agreement and distinguishing Schwartz on the ground that the corpora. tion's purchase of life insurance policies to fund the agreement constituted sufficient consideration). The Schwartz decision has been expressly repudiated by several courts. E.g., Cutter Laboratories, Inc. v. Twining, 221 Cal. App. 2d 302, 313-14, 34 Cal. Rptr. 317,324 (1963).

193. § 514(b) N.Y. Bus. Corp. LAw (McKinney 1963) (adopted 1961, effective Sept. 1, 1963).

194. 12 W. Fletcher, Cyclopedia of the law of Private Corporations \& 5453 (perm. ed. rev. repl. 1957). 2 F. O'NeAL, Close Corporations $\$ 7.14$ (1958), provides an excellent discussion of the advantages of including the restrictive provision in both the charter and a shareholder agreement.

195. The placing of a restrictive provision in the bylaws is sufficient in some states. [2 F. O'Neal, Close Corporatrons $\$ 7.707$ (1958)], but it is safer to use the articles of incorporation.

196. Uniform Stock Transfer Act \& 15; Uniform Commerclal Code $\$$ 8.204. See 2 F. O'NeAL, CLOSE CORPORATIONS $\$ 7.16$ (1958), for a discussion of the amount of information about the restriction which must be noted on the certificate. Some states require quite detailed information. In Michigan, for example, the restrictions imposed on all classes of stock must be stated on each share certificate, irrespective of which class of stock it represents. 2 F. O'NEAL, supra, at 26 n.78.

197. This exemption should not affect the estate tax valuation of the stock since neither the shareholder nor the donee can dispose of the stock for a greater price than that which is payable on the shareholder's death. Cf. Lomb v. Sugden, 82 F.2d 166 (2d Cir. 1936). 
England. ${ }^{108}$ Fortunately, such restrictions are largely a matter of historical interest in this country, for almost all American jurisdictions have rejected the English rule. ${ }^{199}$ Most states, including some whose courts had once accepted that rule, have adopted statutes expressly permitting a corporation to purchase its own shares. ${ }^{200} \mathrm{~A}$ leading commentator on corporate law states that probably no jurisdiction in America would hold that a corporation lacked the power per se to purchase its own stock. ${ }^{201}$ Nevertheless, it may still be prudent to include in the corporation's charter a specific grant of that power. In at least one state, California, the parties may be required to obtain a permit from the appropriate state official to enter into an effective redemption or buy-sell agreement and to transfer shares of stock of certain closely held corporations. ${ }^{202}$ This is an extraordinary requirement, however, and when such permits are required, they are not difficult to acquire.

But even though a corporation will normally have the power to purchase its own shares, that power is not completely unharnessed. Every state imposes restrictions on the exercise of the power, and care must always be taken to observe whatever restrictions are applicable in the relevant jurisdiction. Equitable limitations, for example, bar a corporation from acquiring its own shares if there is a showing of fraud, misrepresentation, breach of fiduciary duty, or similar misconduct. ${ }^{203}$ Such restrictions, however, will not constitute a significant problem when the buy-out agreement is made in good faith.

The financial limitations on stock purchases are of greater significance. These requirements, designed to protect both creditors and the other shareholders, can be divided into three broad cate-

198. Levy, Purchase by an English Company of Its Own Shares, 79 U. PA. L. REv. 45 (1930), discusses the English rule in depth. See also 6A W. FLETcher, Cyclopedia of the Iaw of Private Corporations \$ 2846 (perm. ed. rev. repl. 1968).

199. H. Ballantine, Corporations § 256(a) (1946); 6A WW. Fletcher, Crclopedia of the Law of Private Corporations $\$ 2847-48$ (perm. ed. rev. repl. 1968).

200. Id. See, e.g., Mích. Comp. LAws $\$ 450.10(\mathrm{~h})$ (1948). The statutory citations for each state are set forth in $7 \mathrm{Z}$. Cavitch, Business Organizations $\$ 147.03$, at $811 \mathrm{n.3}$ (1968).

201. Z. Cavitch, Business Organizations $\$ 147.03$ (1968). A few specific types of corporations are prohibited from acquiring their own shares. See, e.g., 12 U.S.C. $\$ 83$ (1964) (restrictions imposed on national banks).

202. Walker, Life Insurance from the Standpoint of the Federal Corporate and Personal Income Tax, Gift Tax, and Estate Tax, U. So. CAL. 1966 TAX INstrtute 543, 548-51.

203. 7 Z. Cavitch, Business Organizations § 147.04(2) (1968). In addition, federal securities laws may impose similar restrictions. See Israels, Corporate Purchase of Its Own Shares-Are There New Overtones?, 50 CORNELI L.Q. 620 (1965). 
gories. $^{204}$ (1) Surplus requirements. Shares must usually be purchased from surplus, which is defined for these purposes in various ways-as earned surplus, as capital surplus plus earned surplus, or simply as any surplus-depending upon state law. A number of states prohibit the impairment of capital, a provision which is essentially the same as requiring that the purchase be made from any surplus. Some state laws permit the use of capital surplus only if a requisite number of shareholders approve, or if the articles permit it. Virtually all of the states, however, have some form of surplus requirement. (2) Solvency. The corporation is often prohibited from purchasing its own shares if it is insolvent or if the purchase would result in its insolvency. ${ }^{205}$ (3) Preferential rights. Sometimes there are statutory provisions requiring that after a purchase, net assets must exceed the value of any preferential right of shareholders on liquidation; such provisions, however, have not been widely adopted. The financial limitations imposed by a given jurisdiction may demand compliance with only one of the above tests or, more typically, with a combination of them.

The word "redemption" or "redeem" has been used heretofore in this Article in the tax sense, that is, to refer to a corporation's acquisition of its own stock in exchange for property. ${ }^{206}$ For corporate law purposes, however, the term "redemption" has a distinctive meaning; it is a corporation's purchase "of its own shares exercised pursuant to pre-existing redemption provisions in the articles or certificate of incorporation." 207 Thus, the difference between redeemable stock and ordinary stock subject to a mandatory entity purchase agreement rests on a subtle distinction; nevertheless, the financial restrictions imposed on stock redemptions are less stringent than those imposed on stock purchases. ${ }^{208}$ Generally, redeemable

204. 7 Z. Cavitch, Business Organizations § 147.04(1) (1968).

205. "Insolvent" in the bankruptcy sense means that the corporation's liabilities exceed its assets. Bankruptcy Act $\$ 1(19), 11$ U.S.C. $\$ 1(19)$ (1964). This test adds little to a surplus test. Some statutes, however, have adopted the equity test of insolvency, that is, the corporation is insolvent if it is unable to pay its debts when they become due in the normal course of business. E.g., CaL. CoRp. Code $\$ 1708$ (West 1955). Some states employ both the bankruptcy and the equity test of insolvency. E.g., MD. ANN. CODE art. $23, \S 32$ (c) (1966).

206. INT. REv. CoDE of 1954, § 317(b).

207. 7 Z. Cavitch, Business Organizations \& 147.05(2) (1968).

208. Id. $\S 147.05(1)$. The same equitable limitations that are applicable to stock purchases apply to redemptions, but the financial limitations are liberalized. For example, the corporation may be permitted to use the stated capital of the redeemed stock for its redemption. In addition, some states grant other special exceptions to the requirement that purchases be made out of surplus-for example, in the situation in which the corporation eliminates fractional shares or pays dissenting shareholders the appraised value of their shares. Id. $\$ 147.04(1)$ (a). Those special exceptions, however, have little significance to buy-out plans. 
stock differs from stock subject to an entity purchase agreement in that the purchase provisions for redeemable stock are an attribute of the stock itself whereas the purchase provisions of nonredeemable stock are the product of contractual agreements. Moreover, redeemable stock is usually preferred stock.

Since there is a risk, then, that financial limitations will prohibit a corporation from purchasing a decedent's stock on the latter's death, any stock purchase agreement should obligate the surviving shareholders to use all available surplus to purchase the stock, and the corporation and the shareholders should agree to take all necessary steps--perhaps short of capital contributions-to provide the corporation with sufficient surplus to make that purchase. In jurisdictions in which local law permits the corporation to use capital surplus only if the articles of incorporation explicitly authorize it to do so, the articles should so provide. If the corporation has appreciated assets, it is possible in some jurisdictions to "write up" the appreciation on the corporation's books and thereby to create an appraisal surplus. The agreement should also require that if the corporation does not purchase the deceased shareholder's stock after a given period of time, then the surviving shareholders shall either make the payments on behalf of the corporation as its guarantors, ${ }^{209}$ or purchase the stock on their own behalf. In some circumstances, it may be possible, by taking advantage of the more liberal provisions for purchasing redeemable stock, to recapitalize the corporation so that the deceased shareholder's stock is exchanged for redeemable preferred stock. Such a plan, however, creates great risks because it is uncertain whether a recapitalization after the decedent's death will be effective for this purpose, ${ }^{210}$ and because the preferred stock received after decedent's death is likely to be characterized as section 306 stock. $^{211}$

\section{Cross-Purchase Plans}

Although the entity purchase is the most popular form of buyout, it is not always the best. Sometimes a cross-purchase plan, in which the surviving shareholders purchase the interest of a deceased

209. The secondary liability of the surviving shareholders will not cause payments made by the corporation as primary obligor to be treated as dividends to them. See note 179 supra and accompanying text.

210. The success of this arrangement may depend upon whether or not all of the shareholders either consent to the recapitalization or had consented to it in a prior shareholder's agreement.

211. See note 29 supra. If the redemption qualifies under $\$ 303$ of the Code, it will not matter that the redeemed shares were "section 306" stock. Treas. Reg. $\$ 1.303-2$ (d) (1955). 
shareholder, will be more advantageous, since it eliminates a number of the risks which attend the entity purchase.

\section{A. Advantages of the Cross-Purchase Plan}

When the stock of a corporation is held by several family groups, the cross-purchase arrangement is a useful way to provide for the purchase of a decedent's stock without disturbing the balance of power over the control of the corporation. An illustration may be helpful:

IV-A-1. The $X$ Corporation has one hundred shares of common stock outstanding; thirty shares are owned by Joseph Smith, thirty shares by Joseph's brother, Robert Smith, twenty shares by Paul Rand and twenty shares by Paul's sister, Rose Rand. The Smiths want a buy-out agreement for their stock, but if the stock of either Smith brother were redeemed by the corporation pursuant to an entity purchase plan, control of the corporation would pass to the Rand family who would then possess over $57 \%$ of the corporation's common stock. The Smiths could execute a cross-purchase agreement between themselves so that on the death of one Smith, his brother would purchase his stock, thus retaining control of $X$ in the Smith family.

The dilemma of the Smith family, however, might also be resolved by means that permit the use of an entity purchase plan. For example, the $X$ Corporation could be recapitalized so that its outstanding common stock would be exchanged for common and preferred stock. ${ }^{212}$ The corporation could then execute a buy-out agreement to purchase the preferred stock of a shareholder upon his demise. Since only preferred stock could be redeemed under the agreement, there would be no shift of control; and if the preferred stock were owned by the decedent at the time of his death, it would not constitute section 306 stock. ${ }^{213}$ Of course, a corollary to that advantage is that if the decedent's estate or legatee received preferred stock as a stock dividend or pursuant to a recapitalization after the decedent's death, the sale of that preferred stock may well

212. A recapitalization of this nature will usually cause no recognition of income to the shareholders. INr. REv. CODE of 1954, \$\$ 354(a), 368(a)(1)(E). Alternatively, the $X$ Corporation could simply distribute preferred stock to its shareholders as a tax-free stock dividend. INT. REv. CODE of 1954, § 305.

213. Since the basis of stock included in a decedent's gross estate will not be a substituted or transferred basis (§ 1014), preferred stock so held by a decedent at his death does not fall within the definition of "section 306" stock. INT. REv. CODE of 1954, $\$ 306(\mathrm{c})$. See note 29 supra. Even if the recapitalization of $X$ were effected after the decedent's demise, the decedent's preferred stock could be redeemed without adverse consequences under $\S 306$ to the extent that the amount received for the stock is within the protection of § 303. INT. REv. CODE of 1954, § 303(c); Treas. Reg. § 1.303-2(d) (1955); see note 15 supra. 
be tainted by section 306 and consequently may cause the recognition of ordinary income on the sale. An additional problem is that the amount distributed by $X$ in redemption of the decedent's preferred stock might be treated as essentially equivalent to a dividend, and consequently taxed as ordinary income, unless the distribution were protected by section 303 or unless the redemption were deemed, under section $302(b)(1)$ or possibly under section 346,214 to be not essentially equivalent to dividend. While there is some support for the exclusion of such a redemption from dividend treatment under section $302(\mathrm{~b})(\mathrm{l}),{ }^{215}$ the uncertainty as to the applicability of that exception might well deter the parties from adopting a plan of this nature unless they are reasonably certain that the mechanical, and therefore more readily ascertainable, requisites for protection under section 303 will be satisfied. Moreover, even if the potential dividend problem could be resolved, the Rands might refuse to permit a recapitalization of $X$ or the execution of an entity purchase agreement. In that event, a cross-purchase plan would be the only viable alternative. Thus, while the cross-purchase plan is usually not the only possible means for effecting a mandatory purchase at death without disrupting the lines of corporate control, it is a useful device for that purpose, and at times it is the only available means. Another possible method for maintaining control, and one that will be the most desirable in some circumstances, is to combine an entity purchase plan for part of a decedent's stock with a cross-purchase plan to acquire the remainder of it.

Since a corporation's accumulation of earnings as a reserve for redemption of stock increases the net asset value of the corporation, it causes the book value of the corporation's stock to rise. Thus, if a deceased shareholder's estate is to receive the actual value of its stock, accumulating funds for an entity purchase drives the redemption price of the stock upwards. This spiralling effect does not occur in a cross-purchase arrangement. The use of a cross-purchase plan also avoids some of the tax problems that attend an entity purchase; the risk that an accumulated earnings tax will be imposed, for example, does not arise, nor does the risk that payments in redemption of stock will be characterized as dividend income. Nevertheless, as noted below, the cross-purchase plan does create other tax problems which may be equally serious in some cases.210

A further advantage to a cross-purchase is that the surviving

214. See notes 17,58 supra.

215. See Commissioner v. Estate of Antrim, 395 F.2d 430 (4th Cir. 1968), affg. 36 P-H Tax Ct. Mem. \67,060 (1967).

216. See note 29 supra and text accompanying notes 231-33 infra. 
shareholders will acquire a basis in the decedent's stock equal to the purchase price. The significance of obtaining that basis depends upon whether or not they subsequently sell the stock, cause the complete or partial liquidation of the corporation, or receive distributions from the corporation in excess of its earnings and profits. The acquisition of a useful basis for the purchased stock is a small advantage, but one which could be meaningful.

Frequently, the surviving shareholders will purchase the decedent's stock with funds obtained from the corporation or from the proceeds of insurance whose premiums were paid with corporate funds. In either case, the net cost of the cross-purchase is usually higher than that of the entity purchase plan. ${ }^{217}$ The sole exception is the situation in which the shareholders are in a lower income tax bracket than the corporation and the needed funds can be withdrawn from the corporation in some tax deductible form, such as rent or salary, over a period of years. This withdrawal must be spread over a number of years because the tax imposed on the distribution of a large sum in one year is usually greater than the tax payable by the corporation, and in that event making the distribution deductible will not suffice to render the cross-purchase less expensive. In addition, the shareholders must face financial and equitable limitations imposed by state corporate law on the corporation's power to make distributions to shareholders, in their capacity as shareholders, when it is impossible to withdraw the needed funds as a business expense of the corporation. In the rare instance in which these hurdles can be overcome, a cross-purchase will be less expensive than an entity purchase, but in the more typical situation, a comparison of net costs will not favor the cross-purchase plan.

Thus, the primary advantages of a cross-purchase are the ease with which control can be retained in one group and the avoidance of certain tax risks. If these advantages should lead to the choice of such a buy-out arrangement, the mechanics of the agreement are the next consideration. Many of these mechanics are identical to those of entity purchase plans, but some-particularly those involved with funding-pose particular difficulties.

\section{B. Similarities to the Entity Purchase}

As with the entity purchase, one of the first steps in preparing a cross-purchase is the determination of the price. The various means available for establishing the price do not change with the

217. See text accompanying notes $38-43$ supra. 
type of agreement. ${ }^{218}$ Similarly, it is desirable to impose restrictions on the inter vivos transfer of shares, regardless of the identity of the purchaser; unless there are restrictions on the shareholders' transfer of stock, the buy-out agreement will not prevent a third party from purchasing a shareholder's stock before his death and will not establish the estate tax value of the stock. The considerations applicable to the restriction of the transfer of stock subject to an entity purchase agreement ${ }^{219}$ are equally applicable to stock subject to a crosspurchase plan. Consequently, restrictions on stock transfers should be included in the corporation's charter as well as in the shareholder's agreement, and such restrictions should be noted on the face of the stock certificates. ${ }^{220}$

Another area of similarity between the two types of buy-outs is the effect of the buy-out on the decedent's estate. A planner should take precautions to ensure that a cross-purchase establishes the estate tax value of the decedent's shares. To do this, the agreement must be a bona fide, arm's-length bargain, the price must be reasonable, the decedent's estate must be obligated to sell, and the decedent must not be permitted to sell during his life for a price greater than that established in the agreement..221

The proceeds of a life insurance policy will not be included in the insured's gross estate for estate tax purposes unless the insured died possessing incidents of ownership in the policy ${ }^{222}$ or unless the policy proceeds were payable to the insured's executor. ${ }^{223}$ If, however, the proceeds are included in the decedent's estate, but distribution of those proceeds is conditioned on the surrender of the insured's stock in the corporation, the estate tax value of that stock will be reduced by an amount equal to the insurance proceeds. ${ }^{224}$ In the interests of caution, then, the insured should usually avoid possessing incidents of ownership in an insurance policy held by a fellow shareholder to fund a purchase agreement.

If the stock is included in the decedent's gross estate for estate tax purposes, the estate should not suffer adverse income tax conse-

218. For a discussion of those means, see text accompanying notes 31-36 supra.

219. See notes 184-97 supra and accompanying text.

220. For a discussion of the requirements for imposing effective restrictions on stock transfers, see notes 194-97 supra and accompanying text.

221. See notes 8-12 supra and accompanying text.

222. The term "incidents of ownership" is defined in Treas. Reg. $\$ 20.2042-1(c)(2)$ (1958).

223. INT. REv. CODE of 1954, \$ 2042(1).

224. See, e.g., Estate of John T.H. Mitchell, 37 B.T.A. 1 (1938), acq., 1938-1 Cum. BuLl. 20. See note 133 supra and accompanying text. 
quences from the sale of that stock. Under section 1014 of the Code, the estate's basis in the stock is equal to its fair market value at the date of the decedent's death; and since executors usually sell the stock for a price equal to its value at the date of death, ${ }^{225}$ there is generally no gain or loss. Moreover, if the stock is included in the decedent's gross estate, and if there is no reorganization or stock dividend after his death, section 306 will not create difficulties. ${ }^{226}$

\section{G. Funding}

\section{Life Insurance Funding}

Life insurance is commonly used to fund cross-purchase agreements, and often the premiums for the insurance are derived from corporate distributions to the shareholders. If this means of funding is used, every shareholder will purchase insurance on the life of each of the other shareholders. The premiums paid on such policies, however, are usually not deductible as business expenditures; $; 27$ even if the insurance premiums are deemed incidental to the shareholder's business, they will still not be deductible expenses. ${ }^{228}$

Another disadvantage of cross-purchase plans which are funded with life insurance is that the complexity of having multiple insurance policies held by the shareholders can become burdensome when the corporation has more than two shareholders. An example may be useful:

IV-C-1. The $X$ Corporation has three equal shareholders, $A, B$, and $C$. The agreed net worth of $X$ is $\$ 300,000$. The three shareholders execute a cross-purchase agreement under which the surviving two shareholders will purchase the stock of the first to die for $\$ 100,000$, and the last surviving shareholder will purchase the stock of the second to die for $\$ 150,000$. Accordingly, $A$ purchases two $\$ 50,000$ life insurance policies, one on the life of $B$ and one on $C ; B$ purchases $\$ 50,000$ insurance on the lives of both $A$ and $C$; and $C$ purchases $\$ 50,000$ life insurance on the lives of both $A$ and $B$. The plan

225. Of course, if the alternate valuation date is elected (INT. REv. CoDE of 1954, $\S 2032$ ), that date controls. In any event, when the buy-sell agreement establishes the estate tax value of the stock, the stock's basis will be identical to the amount of the purchase price.

226. INT. REv. CODE of 1954, § 306(c)(1); see note 29 supra.

227. If it is not a business expense, no deduction is allowed. INT. REv. ConE of $1954, \S 262$.

228. Section 264 of the Code denies an income tax deduction for premiums paid to insure the life of a person financially interested in any of the taxpayer's trades or businesses if the taxpayer is directly or indirectly a beneficiary of the policy. See also INT. REv. CODE of $1954, \S 265$. 
requires the purchase of six policies; if there had been four shareholders, they would have needed twelve policies.220

The difficulties of $A, B$, and $C$ have just begun. When one of the shareholders dies, the buy-out arrangement between the two survivors creates additional problems:

IV-C-2. Continuing the facts of example IV-C-1, $A$ dies and $B$ and $C$ each collects $\$ 50,000$ insurance proceeds which they use to purchase $A$ 's stock. The insurance proceeds received by $B$ and $C$ are not included in their gross income for income tax purposes. 230 After purchasing $A^{\prime}$ 's stock, $B$ and $C$ each has an obligation to pay $\$ 150,000$ for the other's stock if the other dies next. However, $B$ has only $\$ 50,000$ insurance on $C$ 's life, and vice versa. $B$ and $C$ could increase their insurance funding by purchasing new policies, but it would be less expensive to acquire an existing policy. Consequently, $B$ will want to purchase from $A$ 's estate the policy $A$ owned on $C$ 's life, and $C$ would like to purchase the policy $A$ held on $B$ 's life. That will still leave $B$ and $C \$ 50,000$ short in their funding, and they will also face a serious problem in the transfer-for-value rule. ${ }^{231}$ When $B$ dies, and $C$ collects $\$ 100,000$ insurance proceeds, $C$ is not taxed on the $\$ 50,000$ proceeds from the policy he originally acquired from the insurer. But under the transfer-for-value rule, $C$ is taxed on the proceeds from the insurance policy he purchased from $A$ 's estate to the extent that those proceeds exceed the consideration paid by $C$ plus the premiums subsequently paid by him..$^{232}$

One method of avoiding a multiplicity of policies and, perhaps, the transfer-for-value rule is to utilize a trust arrangement for the cross-purchase plan:

IV-C-3. Returning to the facts of example IV-C-I, the three shareholders establish a trust and the trust acquires a $\$ 100,000$ life insurance policy on the life of each shareholder. On the death of $A$, the trustee collects the proceeds and purchases $A$ 's stock. Thus, only three insurance policies are needed instead of six. When $B$ subse-

229. A trust arrangement may be used to avoid this plethora of policies. See text following note 232 infra.

230. INT. REv. CODE of 1954, § 101(a)(1).

231. When an insurance policy is transferred to a party for valuable consideration, the exemption from income tax provided for insurance proceeds under $\$ 101$ is not applicable [\$101(a)(2)], since the recipient of the proceeds may exclude from his income only that portion of the amount of proceeds which is equal to the consideration paid by the transferce plus the premiums paid subsequent to the transfer. Certain classes of persons, however, are exempted from the transfer-for-value rule; for example, a transfer for value to a partner of the insured or to a corporation in which the insured is a sharcholder or officer does not cause the insurance proceeds to be included in the transferee's gtoss income. INT. REv. CoDE of 1954, § 101(a)(2)(B). But there is no exception for transfers to a fellow shareholder of a corporation in which the insured holds stock.

232. INT. REv. CODE of 1954, \& 101 (a)(2). 
quently dies, there is a possibility that the transfer-for-value rule will cause the proceeds of $B^{\prime}$ 's insurance to be taxed in part; 233 but the applicability of that rule to trust arrangements is unsettled. Of course, even this method provides only $\$ 100,000$ insurance for the $\$ 150,000$ obligation of the two surviving shareholders.

At this juncture, the fundamental financial soundness of life insurance funding for cross-purchase plans should be called into question.

IV-C-4. $A$ and $B$ are equal shareholders of the $X$ Corporation which has a net worth of $\$ 100,000$. $A$ and $B$ execute a cross-purchase agreement establishing the price of each other's stock at $\$ 50,000$. $A$ purchases a $\$ 50,000$ life insurance policy on $B$ 's life, and $B$ reciprocates. $A$ and $B$ are the same age and the premiums for their policies are identical. Each of them pays premiums of $\$ 1,600$ per year for the policy he holds on the other's life. After three years (and three premium payments) $A$ dies and $B$ collects the $\$ 50,000$ insurance and purchases $A$ 's stock with the proceeds. The cash surrender value of $B$ 's policy at the time of $A$ 's death is $\$ 500$.

The most significant aspect of this example is that, in substance, $A$ received only 500 dollars for his 50,000 dollar interest in the $X$ Corporation. If the parties had not executed a buy-out agreement, $A$ could have used the money he paid for premiums on $B$ 's life to purchase a 50,000 dollar insurance policy on his own life, and upon his death his estate would then have had the 50,000 dollars insurance proceeds plus a one-half interest in the corporation. Under the buyout plan, $A$ 's estate did receive 50,000 dollars from $B$, but the insurance policy which the estate retained was on $B$ 's life, and had a cash value of only 500 dollars at $A$ 's death. In effect, then, $A$ exchanged his share of the business for the 500 dollar value of the policy on $B$ 's life.

If the ages of the shareholders differ significantly, the problem is ameliorated, because the older shareholder will pay a smaller premium for insurance on the younger man's life than he would pay for insurance on his own life, and because the converse will be true for the younger man. Since it is probable that the younger man will survive and reap the rewards of the buy-out arrangement, it is fair to impose the greater burden on him. In such a situation, insurance funding of a cross-purchase is not as inequitable as it is when the

233. Professor Polasky points out that upon the death of $A$ there was a shifting of the equitable interests of $B$ and $C$ in the policy insuring $B$ 's life, and that this shift may constitute a transfer of an interest in the policy. Polasky suggests that since the transfer of equitable interests is made for mutual consideration, it may trigger the transfer-for-value rule. See Polasky, Planning for the Disposition of a Substantial Interest in a Closely Held Business (pt. III), 46 IowA L. Rev. 516,526 n.38 (1961). 
shareholders' ages are close, but the arrangement still favors the survivor to a considerable extent. ${ }^{234}$ Thus, in most cases, insurance funding of cross-purchase agreements greatly favors the survivors, and the parties should be informed of that fact before they enter into such agreements.

On the other hand, if the parties do not wish to provide a deceased shareholder with a significant sum of money for his stock, there can be tax advantages to the use of a cross-purchase arrangement funded by life insurance. If, instead of that arrangement, $A$ and $B$ simply agree that when either dies, that person's estate will receive only 500 dollars for his stock, and if each party acquires his own insurance protection, the insurance proceeds will be included in the deceased shareholder's gross estate; and the corporate stock will be included at a valuation that may be far in excess of the 500 dollar payment.235 Thus, if the decedent had purchased a 50,000 dollar life insurance policy, the 50,000 dollar insurance proceeds plus the 50,000 dollar value of the decedent's stock will be included in the decedent's gross estate. ${ }^{236}$ If, however, a crosspurchase buy-out arrangement is employed, only the 50,000 dollar value of the decedent's stock plus the 500 dollar value of the survivor's policy will be included, resulting in a reduction of 49,500 dollars in the decedent's gross estate.

When life insurance is used as a means of funding a cross-purchase plan, the parties should also consider the benefits of the several settlement options available under the policy. The considerations in using such options in a cross-purchase plan are essentially the same as those discussed above for the entity purchase. ${ }^{237}$

Some commentators ${ }^{238}$ have suggested that a cross-purchase arrangement might be employed in conjunction with split-dollar insurance in order to minimize the costs of the plan. Such an arrangement,

234. But see Abrams, Tax Planning for Agreements Disposing of a Shareholder's Closely Held Stock at Death, 57 GEo. L.J. 1211, 1215-16 (1969) (contending that the imposition of a greater premium burden on the younger shareholder, who often lacks liquidity, is unfair; and that this imbalance is magnified when the older shareholder possesses more stock than the younger so that a greater principal amount of insurance is required to fund the purchase of the older man's stock).

235. A $\$ 500$ purchase price for the decedent's stock might not be regarded a bona fide price, and in that case it would not fix the estate tax value of the decedent's stock.

236. A shareholder might remove the insurance proceeds from his estate by assigning it during his life to a beneficiary or to an insurance trust. But the advantages and pitfalls of assigning insurance and employing an insurance trust are beyond the scope of this Article.

237. See pt. III.B.2.b. supra.

238. See, e.g., Note, Estate Planning for the Disposition of a Family Corporation, 52 MINN. L. REv. 1019, 1030 n.46 (1968). 
however, is not recommended. Split-dollar insurance is a technique by which an employer may provide life insurance benefits for its employees at a minimum tax cost to them. Under a splitdollar arrangement, an ordinary life insurance policy is issued on the life of an employee. The employer provides the funds for that part of the premium that is equal to the increase in the policy's cash surrender value for the year of the payment, and the employee provides the funds for the balance of the premium. Upon the employee's demise, or upon a surrender of the insurance policy, that amount of the policy's proceeds which is equal to the total funds provided by the employer will be paid to the employer, and the remainder of the proceeds are payable to the beneficiary named by the employee. Thus, in the initial years of the policy, when there is little or no cash surrender value, virtually all of the premiums are paid by the employee. As the policy's cash value builds, the amount of the annual premium payable by the employee is reduced; and after a number of years, the employee may not be required to make any payment at all. On the other hand, since the amount provided by the employer is a charge against the proceeds of the policy, each additional contribution of the employer diminishes the amount of proceeds payable to the employee's beneficiary; consequently, the effect of the plan to the employee is essentially the same as providing him with declining term life insurance-the employee has no equity in the policy and his insurance coverage is reduced each year.

In 1964, the Commissioner revoked an earlier ruling ${ }^{220}$ which had determined that a split-dollar arrangement did not cause the employee to recognize gross income. In his new ruling, ${ }^{240}$ the Commissioner determined that the employee recognizes gross income each year to the extent that the value of the insurance provided him for that year-the cost of term insurance coverage ${ }^{241}$-exceeds the amount of premium paid by the employee for such year.

Under a split-dollar arrangement, the employee will not recognize any taxable income in the initial years of the policy, but he will recognize an increasingly greater amount of income in each subse-

239. Rev. Rul. 55-713, 1955-2 CuM. BuLL. 23.

240. Rev. Rul. 64-328, 1964-2 Cum. BuLl. 11.

241. The value of the insurance provided the employee is usually ascertained by determining the cost per $\$ 1,000$ of term insurance, as established in tables promulgated in the Service's rulings. Rev. Rul. 55-747, 1955-2 Cum. Bull. 228; Rev. Rul. 66-110, 1966-1 Cum. Bull. 12. If, however, the employee's insurer has published rates for term insurance which are lower than the rates set forth in the Service's rulings, and if the insurer's lower published rates are available to all standard risk applicants, then the insurance cost may be determined by using the insurer's rates. Rev. Rul. 66-110, 1966-1 Cum. Bull. 12; Rev. Rul. 67-154, 1967-1 Cum. BuLL. 11. 
quent year, whether the policy is held by the employer or by the employee. $^{2+2}$ Moreover, even though the employee must recognize income, the Commissioner maintains that the employer is not permitted any tax deduction for its payment of premiums because it is a direct or indirect beneficiary of the policy within the meaning of section 264 of the Code, which bars deductions in such cases. ${ }^{243}$

If split-dollar insurance is employed to fund a cross-purchase plan, the arrangement will be similar to the following example:

IV-C-5. The $X$ Corporation, which has a net worth of $\$ 100,000$, has two equal shareholders, $A$ and $B$, both of whom are also employed by $X$. $A$ and $B$ execute a cross-purchase agreement for the mandatory purchase of the stock of whoever dies first. The purchase price of $\$ 50,000$ is to be funded by life insurance, the premiums for which will be paid under a split-dollar plan. Thus, the $X$ Corporation will take out a policy insuring $A$ 's life for $\$ 50,000$; $X$ will pay the premiums for the policy up to its cash surrender value, and $B$ will pay the balance of the premiums. Upon $A$ 's death, the proceeds of the policy, less its cash value which is payable to $X$, will be paid to $A$ 's estate on behalf of $B$ as part or all of the purchase price payable by $B$ on account of the buy-out agreement. $X$ will provide a reciprocal arrangement for $B$, and $A$ will share in the premium payments for the policy on $B$ 's life.

This arrangement, however, has many drawbacks and should not be employed. Referring to example IV-C-5, the amount of insurance coverage under a split-dollar plan declines each year as the cash value increases, and consequently, $A$ and $B$ will have to establish an additional reserve fund to supplement their declining insurance coverage. Moreover, $A$ and $B$ will recognize an increasing amount of gross income each year, and yet the Service apparently will not allow the $X$ Corporation any tax deduction. Thus, this arrangement could be a far more expensive method of funding than is the method of withdrawing sufficient funds from $X$ to purchase a declining term policy, particularly if those funds could be withdrawn in a deductible form. Even if these two objections do not deter the use of a split-dollar plan, there is an additional reason for avoiding it. Under such a plan, $A$ and $B$ each receives term insurance coverage of his fellow shareholder as compensation for services rendered (or arguably, in some cases, as a dividend). Consequently, $A$ and $B$ may be deemed transferees for value of the insurance-that is, to the extent that they recognized income, they purchased that portion of the insurance coverage from the $X$ Corporation

242. Rev. Rul. 64-328, 1964-2 CuM. BuLL. 11.

243. Rev. Rul. 64-328, 1964-2 CuMr. BuLl. 11. 
rather than directly from the insurer; and this determination may be made whether the policies are held by the $X$ Corporation or by $A$ and $B$ individually. But since the policy acquired by or on behalf of $A$ provides insurance on the life of $B$ and vice versa, neither $A$ nor $B$ qualifies for any of the exceptions ${ }^{244}$ to the transfer-for-value rule. Therefore, it is quite possible that the recipient of the policy proceeds will be required to include in his gross income the amount of these proceeds, reduced by the amount of premiums he paid plus the amount of income he previously recognized under the split-dollar plan. ${ }^{245}$ The tax consequences of such treatment are likely to be so severe that the risk cannot be assumed.

\section{Other Means of Funding-Particular Difficulties with the Cross-Purchase}

If life insurance is not used to fund a cross-purchase, and if the surviving shareholders do not have sufficient assets to purchase a decedent's stock for cash, those shareholders will probably have to give the decedent's estate their personal interest-bearing notes. ${ }^{240}$ This method has several drawbacks. First, the shareholders may want liquid assets made available for their estates shortly after their demise and therefore may not agree to a long-term note; second, the surviving shareholders may not be able to provide sufficient security that payment will be made on the note when it becomes due; and third, the surviving shareholders must obtain the funds needed to satisfy the note and usually those funds must be withdrawn from the corporation with all the attendant tax problems. ${ }^{247}$ There is one advantage, however, to using notes: since the shareholders may withdraw funds from the corporation gradually over a period of years, there is a greater prospect of casting the corporate distributions in some deductible form. In sum, if the shareholders are willing to accept the risks involved in taking individual notes in exchange for their stock, then such a means of financing may be desirable.

There is another problem, however, which arises in any crosspurchase plan, and which becomes particularly acute if individual notes are to be exchanged for a decedent's stock. That is the possi-

244. INT. REv. CODE of 1954, §§ 101(a)(2)(A), (B).

245. INr. REv. CoDE of 1954, $\$ 101(a)(2)$.

246. If a long-term note is given, interest will be imputed at a $5 \%$ rate [INT. REv. CODE of 1954, $\S 483$; Treas. Reg. $\$ 1.483-1$ (c)(2) (1966)], unless the note bears interest of at least $4 \%$. Treas. Reg. \& 1.483-1(d)(2) (1966). See note 176 supra.

247. See text accompanying notes 39.44 supra. 
bility that when three or more shareholders join in a cross-purchase agreement, one of them might default. The agreement, then, should state specifically whether or not, upon the default of one of the surviving shareholders, the others will have an option to purchase the decedent's stock which was to be sold to the defaulting shareholder, and, if so, on what terms.

\section{CONCLUSION}

Buy-out agreements are an extremely useful planning device, and a virtually endless variety of arrangements are available. Each plan has its own peculiar advantages and disadvantages. There is no single universally correct plan; the one to be used must be selected and tailored to comply with the specific aims of the parties involved and to create only those business and tax risks that the parties are willing to assume.

Buy-out plans may create tax pitfalls which should be avoided or at least minimized to the extent that it is feasible. For the entity purchase, the principal tax problems are the accumulated earnings surtax, the danger that redemptions of a decedent's stock may be treated as essentially equivalent to a dividend, and, in some cases, those difficulties which may be caused by section 306 . The cross-purchase arrangement does not usually create accumulated earnings problems or dividend problems; its principal tax difficulties are the transferfor-value rule when insurance funding is employed, and the consequences of section 306 when the corporation is recapitalized after the shareholder's death. The net cost of the cross-purchase arrangement is usually higher than that of the entity purchase, especially since the shareholders may have difficulty withdrawing from the corporation in a deductible form sufficient amounts to fund the purchase agreement. In both types of buy-out arrangements, a planner must be careful to protect against adverse estate tax consequences caused by the failure to make the redemption price determinative of the estate tax value of the stock.

In determining which type of buy-out plan to employ, the choice will usually depend on a comparison of the net costs of funding, on the relative difficulty in obtaining funds, and on both estate planning and business planning considerations. All of these factors, in turn, reflect potential tax consequences. Thus, although tax minimization should not be the exclusive goal of a buy-out plan, tax consequences must be considered in drafting the plan and will often constitute the greatest single factor.

Many buy-out plans, particularly those funded with life insur- 
ance, greatly favor the surviving shareholders. There are usually business and personal reasons for adopting such plans-namely, the continuation of the business after the decedent's death and the creation of a ready market for the sale of the decedent's stock-but the parties should be fully apprised of the actual consequences of their particular plan so that they can make an informed, intelligent decision concerning its adoption. 